\title{
Remeasuring the HDI by
} Data Envelopement Analysis

Bernhard Mahlberg (bernhard.mahlberg@wu-wien.ac.at)

Michael Obersteiner (oberstei@iiasa.ac.at) and (oberstei@ins.ac.at)

\section{Approved by}

Sten Nilsson

Leader, Forestry Project

18 December 2001

Interim Reports on work of the International Institute for Applied Systems Analysis receive only limited review. Views or opinions expressed herein do not necessarily represent those of the Institute, its National Member Organizations, or other organizations supporting the work. 


\section{Contents}

1 INTRODUCTION

2 DATA 3

3 METHOD $\quad 4$

3.1 Human Development Index (HDI) 4

3.1.1 Aggregation 5

3.2 Data Envelopment Analysis (DEA) 5

3.2.1 Standard model 5

$\begin{array}{llr}\text { 3.3 Model with Weight Restrictions } & 8\end{array}$

4 RESULTS 9

4.1 Introductory Remarks 9

4.2 Human Development Index (HDI) 9

$\begin{array}{ll}\text { 4.3 Basic DEA Model } & 10\end{array}$

4.4 DEA with Weight Restrictions $\quad 11$

4.5 Comparison of Both DEA Indices with the HDI 12

4.6 Discussion of the Difference Between the HDI and DEA Measurements 16

$\begin{array}{lll}5 & \text { CONCLUSION } & 17\end{array}$

$\begin{array}{lc}\text { REFERENCES } & 18\end{array}$

$\begin{array}{lr}\text { APPENDIX } & 20\end{array}$ 


\section{Abstract}

The measurement of human development has a potentially strong impact on how the development gap is viewed and on the formulation of new policies. Therefore correct and fair measurement is of great importance. In this paper, we develop an algorithm to compute comprehensive differentiation rules suitable for measuring human development. We used models from Data Envelopment Analysis (DEA) literature to compare performance in a multiple output setting. The models were evaluated by empirically re-estimating the human development index (HDI). The most notable advantages of DEA models are that they endogenously construct a non-linearly arranged set of best practice countries and that the weights of each indicator entering the HDI is endogenously determined based on an optimization calculus. These weights are allowed to vary thereby accounting for cross-sectional heterogeneity. While country clusters are identified by their similarity, some interesting outliers can also be singled out using DEA. Such outliers are either best practice frontier countries or countries that are locked in an underdevelopment trap. 


\section{Acknowledgments}

The authors gratefully acknowledge valuable comments from Markus Knell from the Österreichischen Nationalbank, Mikulas Luptacik from the Vienna University of Economics and Business Administration, and Shawna Grosskopf from the Oregon State University, as well as from the participants of the $18^{\text {th }}$ European Conference on Operational Research (EURO 2001) in Rotterdam, and the $7^{\text {th }}$ European Workshop on Efficiency and Productivity in Oviedo. 


\section{About the Authors}

Bernhard Mahlberg is Assistant Professor at the Research Institute for European Affairs, Vienna University of Economics and Business Administration. Michael Obersteiner is a research scholar in IIASA's Forestry Project and at the Institute for Advanced Studies, Vienna, Austria. 


\title{
Remeasuring the HDI by Data Envelopment Analysis
}

\author{
Bernhard Mahlberg and Michael Obersteiner
}

\section{Introduction}

The experience in development research of the past fifty years has demonstrated that development is possible but not inevitable. While a few countries have succeeded in rapid societal and economic growth, narrowing the gap between themselves and the more advanced countries and bringing millions of their citizens out of poverty, many more countries have actually seen the development gap grow and poverty increase. Human hardship, injustice, environmental degradation, and illiteracy are not measured when countries are benchmarked according to their Gross Domestic Product (GDP) per capita ranking. The GDP indicator does not measure the 'fitness' of a particular country or society as a whole, but rather summarizes the current state of specific activities within a society. It has little to do with measuring and explaining the advancements of human societies. The GDP indicator also has little predictive power, since it only measures present success and not the probability of increasing human welfare in the long-term, which might depend on a society's capacity to adapt to new environments (Brookfield, 2001). Thus, measurements of human development must be rooted deeper in society and include a multiplicity of differentiating indicators.

Development research has come up with new differentiating rules to measure the states of human development. Such new rules allow for improved differentiation between countries taking into account characteristics that are idiosyncratic to specific aspects of human development. Differentiation rules that comprise a composite of indicators, each summarizing a particular aspect of human welfare, allow for a more comprehensive assessment of human development. Establishing such multiple criteria differentiation rules is intimately connected to a discussion of the ethical basis of weighting each aspect that summarizes a facet of human development relative to other aspects. Tremendous scientific, analytical, and political effort has gone into the process of constructing the Human Development Index (HDI) as a simple, comprehensive, and fair differentiation rule of human welfare.

The human development index has been rather successful in serving as an alternative measure of development that supplements GDP (Sen, 1999a). Based on three distinct components - indicators of longevity, education, and income per head - it is not exclusively focused on economic opulence, which GDP is. Within the limits of these three components, the HDI has served to substantially broaden the empirical attention that the assessment of development processes receives. However, the HDI, which is 
inescapably a crude index, must not be seen as anything other than an introductory move in getting people interested in the rich collection of information that is present in many international multidisciplinary databases, many of which are geographically explicit. The HDI today is something like a flagship indicator comparing the conditio humana in all nations of the world.

As already mentioned, the HDI is a rather crude measure and is, as the inventor Mahbub-ul-Haq claims, 'of the same level of vulgarity as GDP - just one number but a measure that is not as blind to social aspects of human lives as GDP is". Mahbubul-Haq hoped that not only would the HDI be something of an improvement on - or at least a helpful supplement to - GDP, but also that it would serve to broaden public interest in the other variables that are at least equally important to achieve higher levels of human development. Klein (2001) sees the HDI and the other development indices that are tabulated in the United Nations Development Programme's Human Development Report as excellent information sources for further work of economists engaged in development economics. Based on its original intention, the crude index should speak loud and clear and receive intelligent attention. The HDI should serve as a vehicle through which the complex task of transforming societies along a newly adapted development strategy can occur.

In this light a correct measurement of the HDI is of great importance. The HDI has been criticized several times since it was invented and first published. From the academic literature two branches of criticism can be identified. The first addresses the choice of indicators that the Index contains. The tenor is that the HDI fails to measure the real condition of life in a country because important aspects of development are not taken into account such as, for example, the environmental situation, distribution of income, or political stability. As a consequence, the results can lead to an improper assessment of the status of development or the tendencies of development during the last few years. The recently published work of Dasgupta (2001) has added a new point of view to the critical literature. In his opinion, the consideration of what he calls 'a country's productive base' is omitted. This is a country's stock of physical and human capital as well as the natural capital of soil, forests, biodiversity, etc. Taking these parameters into account the assessment of the word development is completely different. The second branch of literature addresses methodological issues. Several alternative computation approaches have been suggested. A good overview of this literature has been given in the recent work of Neumayer (2001).

This paper is in line with the second branch. Our goal is to improve the measurement of the HDI and to make the measurement more scientific. We acknowledge and honor the effort that has been put into reducing the complexity of measuring human development by using three indicators, namely longevity, education, and income per head. This is a major achievement and will not be further scrutinized in this paper; we will, though, build on this achievement. We feel, however, the need to add some value to the measurement of the HDI by improving the computation of the index given the preselected set of indicators. The currently used algorithm for computing the HDI implicitly assumes that countries shall linearly be sorted according to their summarized performance of three indicators, each of which is assigned a fixed and predetermined weight. We argue that human development should (1) be benchmarked using a nonlinear model and empirical information of best practice countries, and (2) the indicator 
weights should be directly derived from the original data set itself and vary across the cross-section allowing for heterogeneity. We, therefore, propose a different method of computing the HDI using Data Envelopment Analysis (DEA), which is capable of accounting for these problems.

\section{Data}

We used the same indicators as those in the World Development Report that is published annually by the United Nations Development Program (UNDP), which are used to compute the Human Development Index (HDI). The four indices that are summarized in the HDI can be derived from the following three categories: longevity, knowledge, and decent standard of living. Longevity is measured in years by life expectancy at birth ranging from 25 to 85 years. For measuring knowledge, two variables have been chosen, namely adult literacy and the combined gross primary, secondary, and tertiary enrolment ratio. Adult literacy is defined as the number of people who can read and write in relation to the whole population of each country. The combined gross enrollment ratio is defined by the following formula:

$$
\begin{aligned}
& \text { combined gross enrollment ratio }= \\
& \text { gross enrollment ratio primary education } * 7 / 17+ \\
& \text { gross enrollment ratio secondary education } * 5 / 17+ \\
& \text { gross enrollment ratio tertiary education } * 5 / 17
\end{aligned}
$$

Both variables of knowledge are measured in percent. The real GDP per capita serves as the standard of living measure. It is given in US Dollar purchasing power parity, ranging from USD 100 to USD 40,000. Table 1: summarizes the statistics of the variables used. A complete listing of the data can be found in the Appendix.

Table 1: Indicators used in the Human Development Index (HDI), 1998.

\section{Mean $\begin{gathered}\text { Standard } \\ \text { Deviation }\end{gathered}$ Minimum Maximum}

\section{Longevity:}

Life expectancy at birth [years]

65.6

10.4

79.9

34.7

Knowledge:

Adult literacy rate [\%]

78.41

22.05

99.0

Combined enrolment ratio [\%]

\section{Decent standard of living:}

Adjusted per capita income [PPP\$] $\quad 6950 \quad 7285 \quad 34004 \quad 355$

Note: Total sample size is 174 .

Source: Own computations on the basis of data from UNDP (1998). 
Our computations are based on data published by the Human Development Report Office (UNDP, 1998). The HDI as well as our DEA driven indices are computed for a large sample of 174 countries from the five continents, ranging from very high to very low human development.

\section{Method}

\subsection{Human Development Index (HDI) ${ }^{1}$}

The HDI is based on three indicators: longevity measured by life expectancy at birth; educational attainment measured by a combination of adult literacy (two-thirds weight) and a combined gross primary, secondary, and tertiary enrolment ratio (one-third weight); and standard of living measured by real GDP per capita (PPP\$).

To construct the index, fixed minimum and maximum values have been established for each of these indicators:

- Life expectancy at birth: 25 years and 85 years.

- Adult literacy rate: $0 \%$ and $100 \%$.

- Combined cross enrolment ratio: $0 \%$ and $100 \%$.

- Real GDP per capita (PPP\$): \$100 and \$40,000 (PPP\$).

Individual indices can be computed for any component of the HDI according to the general formula:

$$
\text { Index }=\frac{\text { actual value }- \text { minimum value }}{\text { maximum value }- \text { minimum value }} .
$$

If, for example, life expectancy at birth in a particular country is 65 years, the index of life expectancy for this country would be:

$$
\text { Life expectancy }=\frac{65-25}{85-25}=\frac{40}{60}=0.667 \text {. }
$$

The construction of the income index is slightly more complex. Income is treated by using the following formula:

$$
\text { Income index }=\frac{\log (\text { actual income })-\log (\text { minimum income })}{\log (\text { maximum income })-\log (\text { minimum income })} \text {. }
$$

\footnotetext{
${ }^{1}$ For details see UNDP (2000: 269).
} 


\subsubsection{Aggregation}

The aggregation is done by the following process:

In the first step, the adult literacy index and the combined cross enrolment index is aggregated to the education attainment index.

Education attainment index $=$

$2 / 3 *$ Adult literacy index +

$1 / 3 *$ combined cross enrolment index.

In the second step, a simple average of the life expectancy index, the educational attainment index, and the adjusted real GDP per capita (PPP\$) index is computed. The sum of three indices is divided by 3 .

With the normalization of the values of the variables that make up the HDI, its value ranges from 0 to 1 . The HDI value of a country shows the distance that it has already moved towards the maximum possible value of 1 and also allows comparisons with other countries. The difference between the value achieved by a country and the maximum possible value shows the country's shortfall and indicates how far the country has to go.

\subsection{Data Envelopment Analysis (DEA)}

\subsubsection{Standard model}

The basic problems when expressing the economic performance in one single indicator are first, to aggregate a number of non-commensurate performance indicators (such as level of national income per capita, life expectancy, etc.) to one single performance measure. And second, to establish a benchmark that can be used for comparing the performance of the countries in the sample.

In most studies, a weighted sum is calculated to aggregate the individual indicators. A good example is the HDI described above. The weights are chosen by the researcher and reflect his preferences. The results of this calculation are influenced by these weights. The assessed countries are ranked with respect to their performance scores. An alternative, suggested by Lovell and Pastor (1994) and Lovell (1995), is the DEA, which is a non-parametric approach that uses a linear programming technique. The DEA defines the best practice frontier that serves as a benchmark and minimizes the relative distance to this benchmark. This distance is interpreted as the economic performance of the countries in the sample. It is equivalent to the weighted sum. The weights are calculated by the DEA within the optimization process.

Farrell (1957) introduced the concept of the best practice frontier, which delineates the technological limits of what a country can achieve with a given level of resources. The solid line in Figure 1: shows the best practice frontier computed by DEA in a situation in which two indicators are combined into one single performance index. Each dot in the diagram (A to D) stands for the performance of a country in the sample. The DEA constructs an envelope for the observed indicator combinations of all countries in the 
sample under the constraint that all well-performing countries support the envelope. The frontier is called best practice frontier and allows us to classify countries into wellperforming units if they are at the frontier and into worse performing units if they lie below. A worse performing country could either augment the indicator number one or number two, or even both. The indicator of performance is then given by the relative distance between the actual observed performance and the nearest benchmark.

In Figure 1, three countries (A, B, and C) support the DEA - best practice frontier and are classified as best performing. Country D lies below the best practice frontier and is identified as worse performing. As a performance indicator we used the radial distance measure developed by Farrell (1957). It is defined as the ratio of the distance between the origin and the projected point of the examined country at the frontier divided by the distance between the origin and the actual observed point. For example, the performance of country $\mathrm{D}$ is $0 \mathrm{D}^{\mathrm{T}} / 0 \mathrm{D}$. The performance score for the best performing countries is 1 and for the worse performing countries it is larger than 1 .

The case shown in Figure 1 is the aggregation of two indicators with the aid of an index-maximizing DEA. An index-maximizing DEA seeks to compute economic performance as a proportional augmentation in all indicators. ${ }^{2}$ The index-maximizing approach is applied if the scores of all indicators are preferred to be as high as possible (e.g., GDP, literacy rate, etc.). ${ }^{3}$

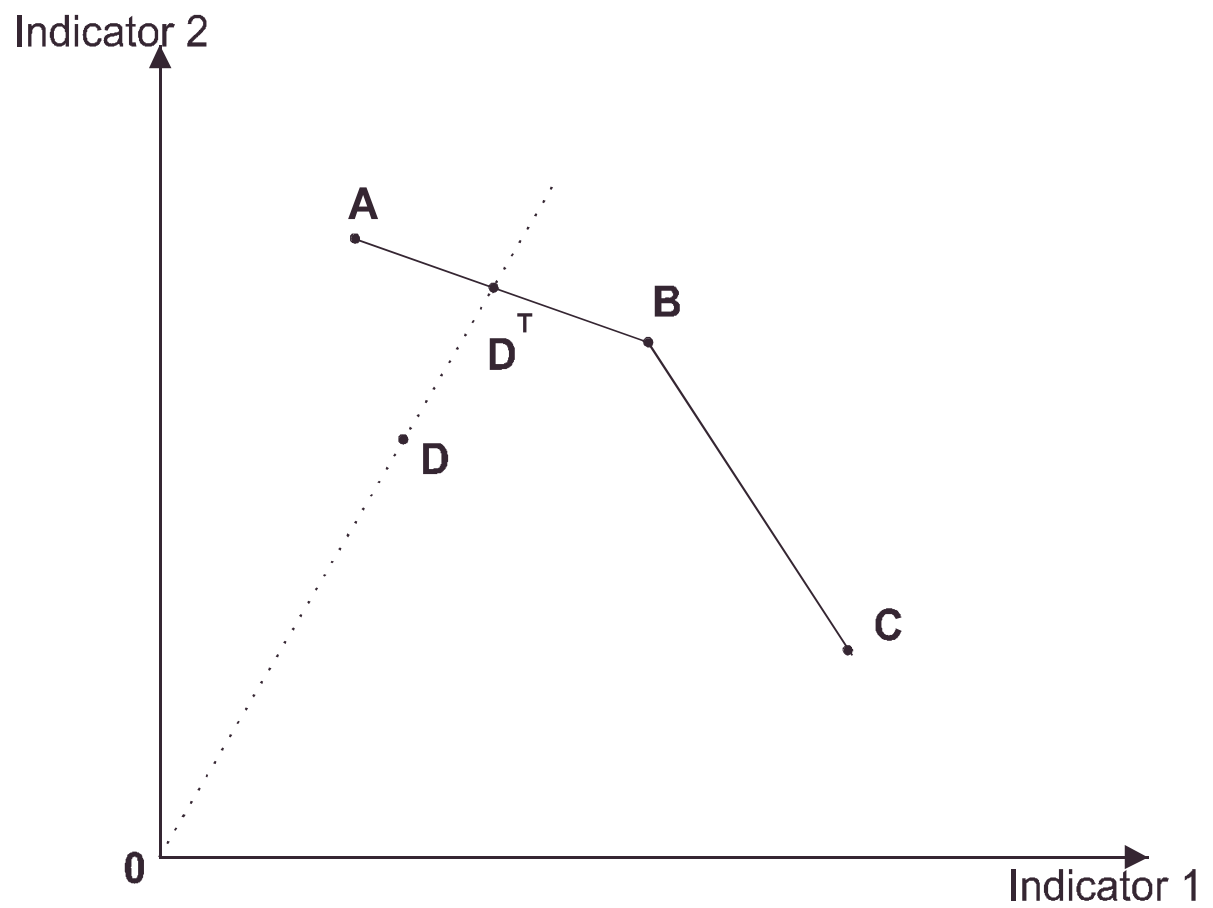

Figure 1: Determining the best performing countries with normal DEA.

2 Another term in literature for this kind of DEA is "output-oriented DEA" (see Coelli et al., 1998: 137).

3 A different way to aggregate indicators is to apply an index-minimizing DEA. This approach is adopted if the scores are preferred to be as low as possible (interest rate, inflation, etc.). In literature, this kind of DEA is usually termed as "input-oriented DEA" (see Coelli et al., 1998: 137). 
The computation of the envelope and the development index can be reduced to a linear program for each individual country in which the following optimization problem is solved: 4

$$
\begin{array}{ll}
\min \sum_{i} v_{i} x_{i 0}=Z_{0} & \\
\text { s.t. } \quad & \sum_{r} \mu_{j} y_{r 0}=1 \\
& -\sum_{r} \mu_{r} y_{r j}+\sum_{i} v_{i} x_{i j} \geq 0 \quad \text { (for each of the } N \text { countries) } \\
& v_{i} \geq \mathcal{E}, \quad \mu_{r} \geq \mathcal{E}
\end{array}
$$

where

$Z_{O} \ldots$ performance score,

$\varepsilon \ldots$ non-archimedean variable $\left(\varepsilon=10^{-8}\right), 5$

$x_{i j} \ldots$ i-th resource of the $j$-th country, $i=1, \ldots, m, m \ldots$ number of resources, $m=1$,

$y_{r j} \ldots \mathrm{r}$-th indicator of the $j$-th country, $r=1, \ldots, \mathrm{s}, \mathrm{s} \ldots$ number of indicators, $s=4$,

$j=1, \ldots, N, N \ldots$ number of countries, $\quad N=174$,

$v_{i} \ldots$ weight of the $i$-th resource,

$\mu_{r} \ldots$ weight of the $r$-th indicator.

This procedure computes the performance score $Z_{O}$ of a single country that is equal to the weighted sum of the four indicators and must be repeated for each country in the sample. Because we combine the four indicators of the HDI, the resource side consists of the unity vector. The model computes the weights so that the country under instigation is ranked as best as possible. Every weight of individual indicators can lie between 0 and 1 and the sum of all weights must be equal to 1 . The weights can differ from country to country in contrast to the standard definition of the HDI, where the weights are equal for all countries.

Figure 1 also shows one particular weakness of the DEA. This model has the characteristic to diagnose any country supporting the frontier to be equally well performing even if it is superior with respect to one indicator but performs poorly with respect to all the others (e.g., C). This weakness is the well-known boundary problem. For such a country, the DEA computes a high weight to the indicator where the country is superior and a low weight to all the other indicators. In an extreme case, the DEA selects a weight of one for that indicator and a weight of zero to the others. Only this indicator is taken into account for computing the performance index. This characteristic makes the results of the basic model implausible.

\footnotetext{
4 This linear program was developed by Charnes et al. (1978).

5 The issues of the appropriate specification of the non-archimedean variable are discussed in Ali (1994:78).
} 
In order to differentiate between different benchmark countries, a ranking procedure could be used, for example, the extended DEA model developed by Andersen and Petersen (1993). Using this technique would not fundamentally improve the results because the main characteristics of the model would not change. Therefore, the flexibility in the selection of weights must be limited to solve the boundary-problem. This is done by applying a DEA model with weight restrictions.

\subsection{Model with Weight Restrictions}

The type of restriction we used is termed in the literature as "Type I Assurance Regions". ${ }^{6}$ This type of restriction is illustrated by restriction A in the following linear program:

$$
\begin{array}{ll}
\min \sum_{i} v_{i} x_{i 0}=Z_{0} & \\
\text { s.t. } \quad & \sum_{r} \mu_{j} y_{r 0}=1 \\
& -\sum_{r} \mu_{r} y_{r j}+\sum_{i} v_{i} x_{i j} \geq 0 \quad \text { (for each of the } N \text { countries) } \\
& \alpha \leq \frac{\mu_{r}}{\mu_{r+1}} \leq \beta \quad \text { restriction } A \\
& v_{i} \geq \varepsilon, \quad \mu_{j} \geq \varepsilon
\end{array}
$$

where

$Z_{O} \ldots$ performance score,

$\varepsilon \ldots$ non-archimedean variable $\left(\varepsilon=10^{-8}\right)$,

$x_{i j} \ldots$ i-th resource of the $j$-th country, $i=1, \ldots, m, \quad m \ldots$ number of resources, $m=1$,

$y_{r j} \ldots$ r-th indicator of the $j$-th country, $r=1, \ldots, s, \quad s \ldots$ number of indicators, $s=4$,

$j=1, \ldots, N, \quad N \ldots$ number of countries, $N=174$,

$v_{i} \ldots$ weight of the i-th resource,

$\mu_{r} .$. weight of the $\mathrm{r}$-th indicator,

$\alpha, \beta \ldots$ lower and upper bound of weight relation.

The flexibility in selecting the weight is limited by setting the positive lower and upper bounds of the relative weights of all four indicators (restriction A). This limitation ensures that no weight can be zero or one. We computed the DEA models with three different intervals of lower and upper bounds $[\alpha, \beta]$, namely $[0.001,1000],[0.01,100]$ and $[0.1,10]$. This linear program also computes the development score $\mathrm{Z}_{0}$ of a single country and must be repeated for each country in the sample. The resource side consists of the unity vector.

6 Allen et al. (1997) gives a good overview about DEA models with weight restrictions. 


\section{$4 \quad$ Results}

\subsection{Introductory Remarks}

Basically, in order to measure the performance of countries, we used different indicators divided into the following three categories: longevity, knowledge, and decent standard of living. Applying the basic DEA model developed by Charnes et al. (1978) and one DEA model with weight restrictions developed by Allen et al. (1997), we computed two performance indices for each country in the sample. Both DEA models are indexmaximizing models.

The scores of both DEA-models are, per definition, 1 or larger and a value of 1 is assigned to the best performing country. By transforming the scores of the DEA to the domain between zero and one, we make the DEA scores comparable to the values of the HDI. The transformation is done by inverting the DEA scores. ${ }^{7}$ The values of the transformed indicators lie between 0 and 1 , as in the values of the HDI. The domain of the HDI, as published in the Human Development Report, is between 0 and 1, but even the best performing country does not achieve the highest possible value. To ensure comparability with the DEA values we normalized the HDI. To the highest developed country a value of 1 is assigned and to all relatively less developed countries a value of less than 1 .

All three indices are interpreted in the same way. The values of both indices show the distance that a country has already moved towards the maximum possible value of 1 and allows comparisons with other countries. The difference between the value achieved by a country and the maximum possible value of 1 shows the country's shortfall and indicates how far the country has to go.

\subsection{Human Development Index (HDI)}

Table 2 shows the transformed HDI scores and the ranks of the top ten countries. The highest developed country is Canada followed by France, Norway, and the USA. Norway and the USA are equally ranked as well as Iceland and France. This shows that the HDI does not discriminate completely and thus some countries are ranked equally.

The weights are determined externally by the designer of the index and are equal for all countries. Therefore, the construction of the index is inflexible because it does not take into account the particular situation of the country shown by the figures.

7 This is a standard procedure for transforming DEA scores. For a description and discussion, see Coelli et al. (1998: 134-160). 
Table 2: Scores and ranking of the Human Development Index.

\begin{tabular}{lcc}
\hline Country & Score & Rank \\
\hline Canada & 1.000 & 1 \\
France & 0.985 & 2 \\
Norway & 0.982 & $\mathbf{3}$ \\
USA & 0.982 & $\mathbf{3}$ \\
Iceland & 0.981 & $\mathbf{5}$ \\
Finland & 0.981 & $\mathbf{5}$ \\
Netherlands & 0.980 & 7 \\
Japan & 0.979 & 8 \\
New Zealand & 0.978 & 9 \\
Sweden & 0.975 & 10 \\
\hline
\end{tabular}

Note: Total sample size is 174 .

Source: Transformed values based on UNDP (1998).

\subsection{Basic DEA Model}

By using DEA we compute endogenous weights and, in this way, we make the HDI more scientific and overcome the inflexibility of the original design. The DEA approach is more flexible because it computes weights, which depend on the data.

Table 3 reports the development score computed by a basic DEA model of a collection of countries. All of the countries listed are ranked first. ${ }^{8}$ One of the main characteristics of the DEA is that it chooses the weights so that each country has the highest possible development score. This is the reason why the DEA computes, for countries that have the highest values of 99 percent in the adult literacy and only relatively poor values in the other indicators, a weight of one for this indicator and a weight of zero for all the others. ${ }^{9}$ This means that the DEA only takes into account the adult literacy for these countries. It turns out that for most of the countries ranked at the top, the adult literacy rate is 99 percent. From a total of 174 countries, 32 are ranked at the top, 27 of which the DEA has computed a weight of 1 for adult literacy.

\footnotetext{
8 The results for all of the countries can be found in the Appendix.

9 The data we used for the computation are reported in the Appendix.
} 
Table 3: Scores, ranking, and weights of the basic DEA model.

\begin{tabular}{lcccccc}
\hline Country & Scores Ranking & $\begin{array}{c}\text { Weight of } \\
\text { life } \\
\text { expectancy }\end{array}$ & $\begin{array}{c}\text { Weight of } \\
\text { adult } \\
\text { literacy }\end{array}$ & $\begin{array}{c}\text { Weight of } \\
\text { enrolment } \\
\text { rate }\end{array}$ & $\begin{array}{c}\text { Weight of } \\
\text { GDP }\end{array}$ \\
\hline Norway & 1 & $\mathbf{1}$ & 0 & 1 & 0 & 0 \\
Poland & 1 & $\mathbf{1}$ & 0 & 1 & 0 & 0 \\
Russian Federation & 1 & $\mathbf{1}$ & 0 & 1 & 0 & 0 \\
Slovakia & 1 & $\mathbf{1}$ & 0 & 1 & 0 & 0 \\
Sweden & 1 & $\mathbf{1}$ & 0 & 1 & 0 & 0 \\
Switzerland & 1 & $\mathbf{1}$ & 0 & 1 & 0 & 0 \\
Tajikistan & 1 & $\mathbf{1}$ & 0 & 1 & 0 & 0 \\
United Kingdom & 1 & $\mathbf{1}$ & 0 & 1 & 0 & 0 \\
USA & 1 & $\mathbf{1}$ & 0 & 0 & 0.56 & 0.44 \\
Uzbekistan & 1 & $\mathbf{1}$ & 0 & 1 & 0 & 0 \\
\hline
\end{tabular}

Note: Total sample size is 174 .

Source: Own computations.

\subsection{DEA with Weight Restrictions}

To improve the discriminating power of the DEA and obtain a realistic and plausible ranking, we impose restrictions on the DEA weight. The relative weight of indicator $i$ to the weight of indicator $j$ is restricted to between 0.01 and 100. In this way, we solve the problem of zero weights completely. None of the indicators are excluded from the analysis and almost none of the countries are ranked equally.

As can be seen from Table 4, no country, among the top 10, is equally ranked with another. The ranking is therefore unambiguous for most countries. Luxembourg is the most developed country followed by Brunei Darussalam and the USA. The following positions are occupied by Switzerland, Canada, and Norway. This ranking is quite plausible. ${ }^{10}$

We have also tried wider and narrower intervals between lower and upper bounds $(0.1$ and 10 as well as 0.001 and 1000). We found that the wider the interval the similar are the results with the outcomes of the basic DEA-model and so the problems of basic DEA model appears again. The narrower the interval the less the room for maneuver for the DEA-procedure to select weights and thus the more the weights are predetermined by the researcher. As a consequence of using wider intervals more then one country is ranked on the same position. With the lower bound of 0.01 and the upper bound of 100 we steered a middle course between too strong predetermination and too large flexibility for the DEA.

10 The complete ranking can be found in the Appendix. 
Table 4: Scores, ranking, and weights of the DEA model with weight restrictions.

\begin{tabular}{lcccccc}
\hline Country & Score & Ranking & $\begin{array}{c}\text { Weight of } \\
\text { life } \\
\text { expectancy }\end{array}$ & $\begin{array}{c}\text { Weight of } \\
\text { adult } \\
\text { literacy }\end{array}$ & $\begin{array}{c}\text { Weight of } \\
\text { enrolment } \\
\text { rate }\end{array}$ & $\begin{array}{c}\text { Weight of } \\
\text { GDP per } \\
\text { capita }\end{array}$ \\
\hline Luxembourg & 1 & $\mathbf{1}$ & 0.002 & 0.225 & 0.001 & 0.772 \\
Brunei Darussalam & 0.972 & $\mathbf{2}$ & 0.163 & 0.002 & 0.160 & 0.675 \\
USA & 0.944 & $\mathbf{3}$ & 0.141 & 0.183 & 0.177 & 0.499 \\
Switzerland & 0.876 & $\mathbf{4}$ & 0.156 & 0.197 & 0.151 & 0.496 \\
Canada & 0.868 & $\mathbf{5}$ & 0.159 & 0.199 & 0.201 & 0.441 \\
Norway & 0.860 & $\mathbf{6}$ & 0.157 & 0.201 & 0.187 & 0.455 \\
Denmark & 0.843 & $\mathbf{7}$ & 0.156 & 0.205 & 0.184 & 0.455 \\
France & 0.835 & $\mathbf{8}$ & 0.165 & 0.207 & 0.186 & 0.443 \\
Belgium & 0.833 & $\mathbf{9}$ & 0.161 & 0.207 & 0.180 & 0.451 \\
Japan & 0.831 & $\mathbf{1 0}$ & 0.168 & 0.208 & 0.164 & 0.461 \\
\hline
\end{tabular}

Note: Total sample size is 174 .

Source: Own computations.

\subsection{Comparison of Both DEA Indices with the HDI}

In this section we compare the results of the original HDI with that of the two DEA models. First, we compare the results of the HDI with the results of the basic DEA model and the DEA model with the weight restrictions by considering descriptive statistics and the histograms. Then we show the similarities and differences with the aid of correlation coefficients. Finally, we work out the similarities and differences by considering the rankings in detail.

The comparison of the values computed by the basic DEA model with the HDI values reveals that the mean of the DEA scores is clearly higher than the values of the HDI. On average, the scores of the DEA model with weight restrictions are the smallest (Table 5). The variation of the scores from the basic DEA model measured by the standard deviation is lower than that of the HDI, whereas the variation of the scores from the DEA with weight restrictions lies in-between. The difference between the highest and the lowest score is the smallest for the basic DEA scores and the highest for scores computed by the DEA with weight restrictions. With respect to the basic DEA index, the countries are nearest to the benchmark country on average.

The histogram of the indices (Figure 2) reveals the following. The index values of the basic DEA model are distributed very unequally. The distribution reaches its maximum between 0.91 and 1 . The majority (52 percent or the values of 91 countries) of the values lie in this class. Less than 20 percent of the scores can be found in each of the other classes. None of the basic DEA scores lie below 0.51 . 
Table 5: Descriptive statistics, HDI scores, and the DEA results.

\begin{tabular}{lccc}
\hline & HDI & Basic DEA & DEA with weight restrictions \\
\hline Mean & 0.654 & 0.852 & 0.446 \\
Median & 0.729 & 0.909 & 0.465 \\
Standard deviation & 0.228 & 0.139 & 0.189 \\
Maximum & 1 & 1 & 1 \\
Minimum & 0.193 & 0.434 & 0.148 \\
\hline
\end{tabular}

Note: Total sample size is 174 .

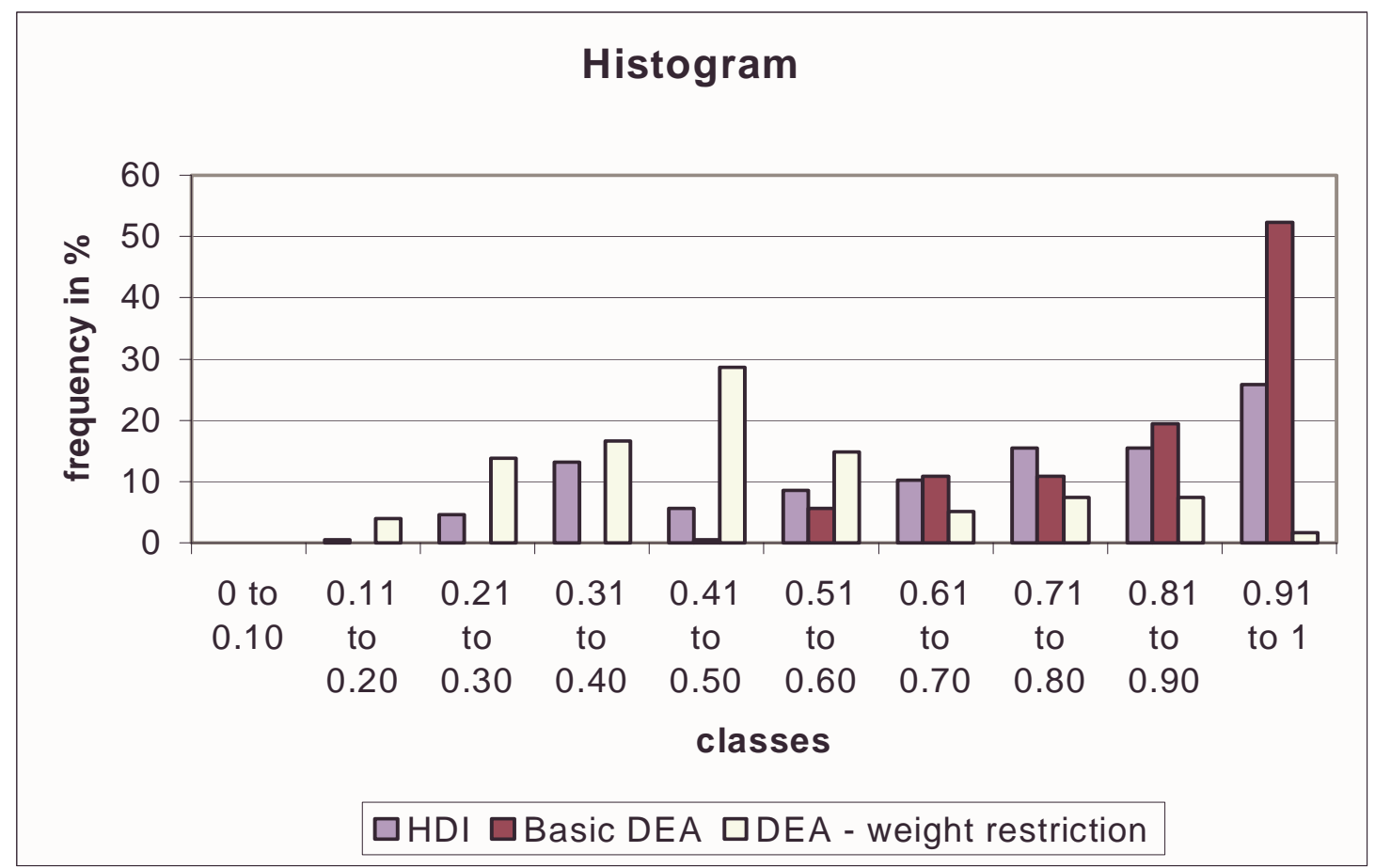

Note: Total sample size is 174 .

Figure 2: Histogram of the index values.

The HDI is also distributed unequally but to a lesser extent. It has its frequency maximum in the class between 0.91 and 1 , however the distribution appears much flatter. Around 26 percent of the scores lie within this class. The rest of the scores are fairly well distributed to the other classes. The variation of the HDI values is higher than the DEA values. According to the HDI fewer countries lie within the upper two classes with values equal to or higher than 0.81 , than according to the basic DEA model.

In contrast to the distributions of the HDI and the basic DEA the scores of the DEA with weight restrictions appears to be almost symmetrical and resembles the shape of the normal distribution. It has its maximum frequency in the class from 0.41 to 0.50 . Twenty-nine percent of the development scores (of 50 countries) are in this class. Almost the same number of countries has scores above or below this class. Only nine countries or two percent have scores above 0.81 . 
The upper part of Table 6 shows the correlation of the index values computed by the HDI and the two DEA models with each other and with the four indicators (life expectancy, adult literacy, enrolment ratio, and GDP per capita), whereas the lower part presents the correlation of the rankings of the three indices with each other and with the ranking of the four indicators.

Table 6: Correlation between the components and the indices.

\begin{tabular}{lccccccc}
\hline & $\begin{array}{c}\text { Life } \\
\text { Expectancy }\end{array}$ & $\begin{array}{c}\text { Adult } \\
\text { literacy }\end{array}$ & $\begin{array}{c}\text { Enrolment } \\
\text { ratio }\end{array}$ & $\begin{array}{c}\text { GDP } \\
\text { per capita }\end{array}$ & HDI & $\begin{array}{c}\text { Basic } \\
\text { DEA }\end{array}$ & $\begin{array}{c}\text { DEA with } \\
\text { weight } \\
\text { restrictions }\end{array}$ \\
\hline $\begin{array}{l}\text { Correlation coefficient } \\
\text { HDI }\end{array}$ & $\mathbf{0 . 9 2 9}$ & 0.847 & 0.856 & 0.734 & 1 & & \\
$\begin{array}{l}\text { Basic DEA } \\
\text { model }\end{array}$ & 0.909 & $\mathbf{0 . 9 1 7}$ & 0.844 & 0.565 & 0.893 & 1 & \\
$\begin{array}{l}\text { DEA with } \\
\text { weight }\end{array}$ & 0.837 & 0.758 & 0.794 & $\mathbf{0 . 9 3 6}$ & $\mathbf{0 . 9 0 1}$ & 0.798 & 1 \\
$\begin{array}{l}\text { restrictions } \\
\text { Spearman rank correlation coefficient }\end{array}$ & & & & & \\
$\begin{array}{l}\text { HDI } \\
\begin{array}{l}\text { Basic DEA } \\
\text { model }\end{array}\end{array}$ & 0.933 & 0.791 & 0.809 & $\mathbf{0 . 9 5 8}$ & 1 & & \\
$\begin{array}{l}\text { DEA with } \\
\text { weight }\end{array}$ & 0.825 & $\mathbf{0 . 9 5 9}$ & 0.772 & 0.716 & 0.831 & 1 & \\
restrictions & 0.917 & 0.812 & 0.820 & $\mathbf{0 . 9 4 9}$ & $\mathbf{0 . 9 8 2}$ & 0.855 & 1 \\
\hline
\end{tabular}

Note: Total sample size is 174 .

The correlation coefficients of the indices with the indicators reveal that any index is strongly correlated with only one particular indicator. None of the indices is equally related with all of the indicators. The values of the HDI are strongly connected with life expectancy, whereas the values of the basic DEA model are highly correlated with adult literacy and the values of the DEA with weight restrictions are related mostly with the GDP per capita. The correlations of the values computed by the three models reveal that the outcomes of the DEA with weight restrictions are most similar with the HDI.

The correlation coefficients of the rankings are quite similar to the correlation coefficients of the values. The only remarkable difference is that the rankings of the HDI are more strongly connected to GDP per capita than to life expectancy. Apart from this difference, the picture is the same as before. The rankings of the scores from the basic DEA model are strongly related to those of adult literacy, and the rankings from the DEA with weight restrictions are strongly correlated with that of GDP per capita. The rankings from the DEA model with weight restriction are strongly correlated to those of the HDI.

Resulting from the fact that the HDI scores are strongly correlated with those of the DEA with weight restrictions as well as the rankings of these models are strongly related together, we conclude that the design of the HDI is quite good. It provides a realistic and plausible picture of the real status of developments and the weights fit quite well to the data. 
Table 7 provides deeper insight into the differences between the three indices and shows the top and bottom five countries of the three rankings. It turns out that all of the top five countries of the HDI ranking and all top five countries of the ranking based on DEA with weight restrictions are also ranked in the first position according to the basic DEA. A total of 32 countries are ranked at the top by the basic DEA model. These facts show that the discriminating power of the basic DEA model is unsatisfactory. The comparison of the ranking according to the HDI with the DEA with weight restrictions shows that two countries (Canada and the USA) are within the top five of both rankings and, thus, these countries are within the top five in all three rankings. The other three countries of the top five are different. Further similarities between the HDI and the ranking of the DEA model with weight restrictions can be found if we consider the bottom five countries. Four of the five countries are included in this group with respect to both techniques but in a slightly different order. The bottom five of the ranking, based on the basic DEA, includes completely different countries (with the exception of Sierra Leone). This is a further sign that the basic DEA does not improve the HDI computation.

Table 7: Top and bottom five countries.

\begin{tabular}{llll}
\hline & HDI & ${\text { Basic DEA } \text { Model }^{3}}^{3}$ & DEA with weight restrictions \\
\hline Top five & Canada & Canada & Luxembourg \\
& France & France & Brunei Darussalam \\
& Norway & Norway & USA \\
& USA $^{1}$ & USA & Switzerland \\
& Finland & \\
& Iceland $^{2}$ & Finland & Canada \\
& & & \\
Bottom five & Burundi & Gambia & Ethiopia \\
& Mali & Guinea & Sierra Leone \\
& Burkina Faso & Burundi & Mali \\
& Niger & Guinea-Bissau & Burkina Faso \\
& Sierra Leone & Sierra Leone & Niger \\
\hline
\end{tabular}

Note: Total sample size is 174 .

${ }^{1}$ Norway and the USA are equally ranked third.

${ }^{2}$ Finland and Iceland are equally ranked fifth.

${ }^{3}$ These 5 and a further 27 countries are ranked at the top because their performance score is equal to one. Due to space restrictions only 5 are listed.

If we consider the complete ranking, we conclude that the distinction between the rankings of the basic DEA model and the HDI is bigger than that of the DEA with weight restrictions and the HDI. The mean differences as well as the largest positive and negative differences between the HDI and the basic DEA are bigger than between the HDI and the DEA with weight restrictions.

The reason for the differences between the rankings lies in the weights used in the aggregation of the four variables. In the HDI the designer of the index predetermines the weights, whereas in DEA the linear program selects the weights. So, they are a result of an optimization process. These DEA weights may be objectively correct, whereas the 
weights of the HDI could be wrong and lead to distortion of the ranking and of the conclusions.

\subsection{Discussion of the Difference Between the HDI and DEA Measurements}

Despite the strong correlation between the HDI and the measure of the DEA with weight restrictions of human development (correlation of values is at least 0.89 and rank correlation is at least 0.83 ), there are also some notable differences between the two measurements. In particular, the upper part of the ranking order changed considerably. This is striking taking into account that differing combinations of the same set of three indicators can entirely explain the difference between the two measurements. We can, thus, conclude that the choice of algorithm used to compute the compound index significantly affects the country ranking. Our results show that there are two main reasons for these differences:

(1) Linearity of the benchmark; and

(2) Subjectivity of weights attached to each indicator of the compound index.

The HDI is an index that is comprised of linear combinations of individual indicators. Changes in indicators are always linear and change the compound index according to their respective weight. Contrarily, DEA is a non-linear model as a number of best performing countries form the efficient frontier. The benchmark frontier is a piece-wise linear approximation of a non-linear best practice 'technology' (see Figure 1) and is constructed in such a way that it envelopes the observations of the input-output relation as tight as possible. This property in part explains why the development gap between OECD countries and developing countries is smaller than measured by the HDI. Likewise, the standard deviations are much smaller in the DEA estimation compared to the HDI measurement.

More important, however, is the assumption made by the HDI that a more or less impartial analyst or group of analysts are capable of determining the weights of the individual indicators entering the index. This is a strong assumption and biases with respect to this arbitrariness should be eliminated as much as possible since such weights can be politically rather sensitive and are prone to intentional manipulations. In DEA the algorithm 'endogenously' determines the weights. In the optimization procedure, shadow values (prices) are calculated based on the structure of the data. In this way, the assumption that optimization (maximization of the total output-input ratio) is appropriate to analyze the data set at hand substitutes subjective judgment. DEA weights are constructed so that they not only account for indicator weights that are free of judgment, but also account for cross-sectional heterogeneity. While judgment on weighting the various indicators entering the compound index always involves unsolvable discussions on ethical issues, ignorance of the cross-sectional heterogeneity and non-linearity in the benchmarks would lead to a situation where apples are compared to pears. Furthermore, it can be expected that with an increasing number of indicators for the construction of more comprehensive indices the differences between the two approaches will increase. Since there is a tendency that indices are becoming 
increasingly more comprehensive, the problems discussed above will become increasingly prevalent.

It can be concluded that the algorithm chosen to compute the HDI depends on the decision whether the HDI should reflect a country's distance to some theoretical benchmark of best practice or should be more data driven and the distance measurement should be endogenously determined. In the latter case, the empirical data in the form of a collection of all the countries determine best practice. The distance measurement between best practice countries and less benchmark countries is determined based on endogenous weights reflecting the structure of the data. These weights are allowed to vary across the cross-section taking into account the heterogeneity of country clusters of different states of development.

\section{Conclusion}

The measurement and analysis of development by multiple criteria has the potential to reformulate development policies. Development policies improve from the analysis of less successful countries and examples of best or better practice. The correct measurement of development, as illustrated by the HDI in this paper, is therefore of great importance. A broader view of development is based on the multiplicity of differentiation rules. First, it provides a more thorough basis for evaluating the state of the conditio humana. Employing more comprehensive measurements enhances the intrinsic relevance of lives and puts less emphasis on measurements of financial opulence (World Bank, 1996).

Second, a more comprehensive measurement of development implicitly leads to broader goals and policies being targeted. Broader goals make policies more consistent, complete, and comprehensive (Stiglitz, 1998a, b). Broader goals are necessary in a world where building blocks of the system are interconnected, for example, changes in education contribute to enhancing freedom, technology, conscious consumer behavior, to name just a few. By focusing on the interconnection and simultaneity, it takes us well beyond the narrow perspective of seeing each indicator in isolation. We live in a world of many institutions involving economic and political markets and by using broader strategies we have to determine how they can supplement and strengthen each other, rather than reduce their effectiveness (North, 2001). Sen (1999b) sees the supportive role of the state as central in enhancing the effective freedom of individuals, for example, in providing public education, health care, social safety nets, good macroeconomic policies and in safeguarding industrial competition and epidemiological and ecological sustainability.

In this paper we aimed at a dual goal. First, strengthening the discussion of multiple differentiation rules measuring human development thereby acknowledging the need for more consistent and comprehensive policies of human development. And second, we propose an alternative algorithm for a more correct computation of the HDI. In applying DEA to the indicators that enter the HDI, the actual measurement of human development becomes scientifically more sound. 


\section{References}

Ali, S. (1994). Computational Aspects of DEA. In: A. Charnes, W.W. Cooper, A.Y. Lewin and L.M. Seiford (eds.) Data Envelopment Analysis: Theory, Metrology, and Application, Norwell, Massachusetts, USA. Chapter 4, pp. 63-88.

Allen, R., A. Athanassopoulos, R. Dyson and E. Thanassoulis (1997). Weight Restrictions and Value Judgments in Data Envelopment Analysis: Evolution, Development and Future Directions. Annals of Operations Research, 73, pp. 1334.

Andersen, P. and N.C. Petersen (1993). A Procedure for Ranking Efficient Units in Data Envelopment Analysis. Management Science, Vol. 39, No. 10, pp. 1261-1264.

Brookfield, J.F.Y. (2001). Predicting the Future. Nature, Vol. 441, pp. 999.

Charnes, A., W.W. Cooper and E. Rhodes (1978). Measuring the Efficiency of Decision Making Units. European Journal of Operational Research, 2, North-Holland, pp. 429-444.

Coelli, T., P.D.S. Rao and G.E. Battese (1998). An Introduction to Efficiency and Productivity Analysis. Kluwer Academic Publishers, Bosten/Dordrecht/London.

Dasgupta, P. (2001). Valuing Objects and Evaluating Policies in Imperfect Economies. The Economic Journal, 111, pp. C1-C29.

Farrell, M.J. (1957). The Measurement of Productive Efficiency. Journal of the Royal Statistical Society, Series A, General 120 (III), pp. 253-281.

Klein, L.R. (2001). A Research Agenda. In: G.M. Meier and J.E. Stiglitz (eds.) Frontiers of Development Economics: The Future in Perspective, Oxford University Press, New York.

Lovell, C.A.K. (1995). Measuring the Macroeconomic Performance of the Taiwanese Economy. International Journal of Production Economics, 39, pp. 165-178.

Lovell, C.A.K. and J.T. Pastor (1994). Macroeconomic Performance of the Sixteen IBRO-American Countries over the period 1980 to 1991. Working Paper 94-07. Department of Statistics and Operations Research, University of Alicante.

Neumayer, E. (2001). The Human Development Index and Sustainability - A Constructive Proposal. Ecological Economics, 39, pp. 101-114.

North, D.C. (2001). Needed: A Theory of Change. In: G.M. Meier and J.E. Stiglitz (eds.) Frontiers of Development Economics: The Future in Perspective, Oxford University Press, New York.

Sen, A. (1999a). Human Development Report 1999. United Nations Development Program, New York.

Sen, A. (1999b). Development as Freedom. Knopf, New York.

Stiglitz, J.E. (1998a). More Instruments and Broader Goals: Moving Toward the PostWashington Consensus. Presented at the WIDER Annual Lecture, at the World Institute for Development Economics Research (WIDER), Helsinki, Finland (January). 
Stiglitz, J.E. (1998b). Towards a New Paradigm for Development: Strategies, Policies, and Processes. Prebisch Lecture at UNCTAD, Geneva, 19 October 1998.

UNDP (1998). Human Development Report 1998. United Nations Development Program (UNDP), Oxford University Press 2000. Available on the Internet: http://www.undp.org/hdro/98.htm.

UNDP (2000). Human Development Report 2000. United Nations Development Program (UNDP), Oxford University Press 2000. Available on the Internet: http://www.undp.org/hdr2000/english/HDR2000.html.

World Bank (1996). Poverty Reduction and the World Bank: Progress and Challenges in the 1990s. The World Bank, Washington DC, USA. 


\section{Appendix}

Table 8: Normalized HDI scores and data.

\begin{tabular}{|c|c|c|c|c|c|c|}
\hline & $\begin{array}{c}\text { HDI } \\
\text { value }\end{array}$ & Rank & $\begin{array}{c}\text { Life } \\
\text { expectancy }\end{array}$ & $\begin{array}{c}\text { Adult } \\
\text { literacy }\end{array}$ & $\begin{array}{c}\text { Enrolment } \\
\text { ratio }\end{array}$ & $\begin{array}{c}\text { GDP } \\
\text { per capita }\end{array}$ \\
\hline Canada & 1 & 1 & 79.1 & 99 & 100 & 21916 \\
\hline France & 0.985 & 2 & 78.7 & 99 & 89 & 21176 \\
\hline Norway & 0.982 & 3 & 77.6 & 99 & 92 & 22427 \\
\hline USA & 0.982 & 3 & 76.4 & 99 & 96 & 26977 \\
\hline Iceland & 0.981 & 5 & 79.2 & 99 & 83 & 21064 \\
\hline Finland & 0.981 & 5 & 76.4 & 99 & 97 & 18547 \\
\hline Netherlands & 0.980 & 7 & 77.5 & 99 & 91 & 19876 \\
\hline Japan & 0.979 & 8 & 79.9 & 99 & 78 & 21930 \\
\hline New Zealand & 0.978 & 9 & 76.6 & 99 & 94 & 17267 \\
\hline Sweden & 0.975 & 10 & 78.4 & 99 & 82 & 19297 \\
\hline Spain & 0.974 & 11 & 77.7 & 97.1 & 90 & 14789 \\
\hline Belgium & 0.972 & 12 & 76.9 & 99 & 86 & 21548 \\
\hline Austria & 0.972 & 12 & 76.7 & 99 & 87 & 21322 \\
\hline United Kingdom & 0.971 & 14 & 76.8 & 99 & 86 & 19302 \\
\hline Australia & 0.971 & 14 & 78.2 & 99 & 79 & 19632 \\
\hline Switzerland & 0.969 & 16 & 78.2 & 99 & 76 & 24881 \\
\hline Ireland & 0.969 & 16 & 76.4 & 99 & 88 & 17590 \\
\hline Denmark & 0.967 & 18 & 75.3 & 99 & 89 & 21983 \\
\hline Germany & 0.964 & 19 & 76.4 & 99 & 81 & 20370 \\
\hline Greece & 0.963 & 20 & 77.9 & 96.7 & 82 & 11636 \\
\hline Italy & 0.960 & 21 & 78 & 98.1 & 73 & 20174 \\
\hline Israel & 0.951 & 22 & 77.5 & 95 & 75 & 16699 \\
\hline Cyprus & 0.951 & 22 & 77.2 & 94 & 79 & 13379 \\
\hline Barbados & 0.947 & 24 & 76 & 97.4 & 77 & 11306 \\
\hline Hong Kong, China & 0.947 & 24 & 79 & 92.2 & 67 & 22950 \\
\hline Luxembourg & 0.938 & 26 & 76.1 & 99 & 58 & 34004 \\
\hline Malta & 0.936 & 27 & 76.5 & 91 & 76 & 13316 \\
\hline Singapore & 0.933 & 28 & 77.1 & 91.1 & 68 & 22604 \\
\hline Antigua and Barbuda & 0.932 & 29 & 75 & 95 & 76 & 9131 \\
\hline Korea, Rep. of & 0.931 & 30 & 71.7 & 98 & 83 & 11594 \\
\hline Chile & 0.930 & 31 & 75.1 & 95.2 & 73 & 9930 \\
\hline Bahamas & 0.930 & 31 & 73.2 & 98.2 & 72 & 15738 \\
\hline Portugal & 0.929 & 33 & 74.8 & 89.6 & 81 & 12674 \\
\hline Costa Rica & 0.926 & 34 & 76.6 & 94.8 & 69 & 5969 \\
\hline Brunei Darussalam & 0.926 & 34 & 75.1 & 88.2 & 74 & 31165 \\
\hline Argentina & 0.925 & 36 & 72.6 & 96.2 & 79 & 8498 \\
\hline Slovenia & 0.924 & 37 & 73.2 & 96 & 74 & 10594 \\
\hline Uruguay & 0.922 & 38 & 72.7 & 97.3 & 76 & 6854 \\
\hline Czech Republic & 0.921 & 39 & 72.4 & 99 & 70 & 9775 \\
\hline Trinidad and Tobago & 0.917 & 40 & 73.1 & 97.9 & 65 & 9437 \\
\hline Dominica & 0.916 & 41 & 73 & 94 & 77 & 6424 \\
\hline Slovakia & 0.911 & 42 & 70.9 & 99 & 72 & 7320 \\
\hline Bahrain & 0.908 & 43 & 72.2 & 85.2 & 84 & 16751 \\
\hline Fiji & 0.905 & 44 & 72.1 & 91.6 & 78 & 6159 \\
\hline Panama & 0.904 & 45 & 73.4 & 90.8 & 72 & 6258 \\
\hline
\end{tabular}




\begin{tabular}{|c|c|c|c|c|c|c|}
\hline & $\begin{array}{l}\text { HDI } \\
\text { value }\end{array}$ & Rank & $\begin{array}{c}\text { Life } \\
\text { expectancy }\end{array}$ & $\begin{array}{c}\text { Adult } \\
\text { literacy }\end{array}$ & $\begin{array}{c}\text { Enrolment } \\
\text { ratio }\end{array}$ & $\begin{array}{c}\text { GDP } \\
\text { per capita }\end{array}$ \\
\hline Venezuela & 0.896 & 46 & 72.3 & 91.1 & 67 & 8090 \\
\hline Hungary & 0.893 & 47 & 68.9 & 99 & 67 & 6793 \\
\hline United Arab Emirates & 0.891 & 48 & 74.4 & 79.2 & 69 & 18008 \\
\hline Mexico & 0.891 & 48 & 72.1 & 89.6 & 67 & 6769 \\
\hline Saint Kitts and Nevis & 0.890 & 50 & 69 & 90 & 78 & 10150 \\
\hline Grenada & 0.886 & 51 & 72 & 98 & 78 & 5425 \\
\hline Poland & 0.886 & 51 & 71.1 & 99 & 79 & 5442 \\
\hline Colombia & 0.885 & 53 & 70.3 & 91.3 & 69 & 6347 \\
\hline Kuwait & 0.883 & 54 & 75.4 & 78.6 & 58 & 23848 \\
\hline Saint Vincent & 0.880 & 55 & 72 & 82 & 78 & 5969 \\
\hline Seychelles & 0.880 & 55 & 72 & 88 & 61 & 7697 \\
\hline Qatar & 0.875 & 57 & 71.1 & 79.4 & 71 & 19772 \\
\hline Saint Lucia & 0.874 & 58 & 71 & 82 & 74 & 6530 \\
\hline Thailand & 0.873 & 59 & 69.5 & 93.8 & 55 & 7742 \\
\hline Malaysia & 0.869 & 60 & 71.4 & 83.5 & 61 & 9572 \\
\hline Mauritius & 0.868 & 61 & 70.9 & 82.9 & 61 & 13294 \\
\hline Brazil & 0.843 & 62 & 66.6 & 83.3 & 72 & 5928 \\
\hline Belize & 0.841 & 63 & 74.2 & 70 & 74 & 5623 \\
\hline Libyan Arab Jamahiriya & 0.840 & 64 & 64.3 & 76.2 & 90 & 6309 \\
\hline Suriname & 0.829 & 65 & 70.9 & 93 & 71 & 4862 \\
\hline Lebanon & 0.829 & 65 & 69.3 & 92.4 & 75 & 4977 \\
\hline Bulgaria & 0.822 & 67 & 71.2 & 98 & 66 & 4604 \\
\hline Belarus & 0.816 & 68 & 69.3 & 97.9 & 80 & 4398 \\
\hline Turkey & 0.815 & 69 & 68.5 & 82.3 & 60 & 5516 \\
\hline Saudi Arabia & 0.810 & 70 & 70.7 & 63 & 57 & 8516 \\
\hline Oman & 0.803 & 71 & 70.3 & 59 & 60 & 9383 \\
\hline Russian Federation & 0.801 & 72 & 65.5 & 99 & 78 & 4531 \\
\hline Ecuador & 0.799 & 73 & 69.5 & 90.1 & 71 & 4602 \\
\hline Romania & 0.799 & 73 & 69.6 & 98 & 62 & 4431 \\
\hline Korea, Dem. People's Rep. of & 0.798 & 75 & 71.6 & 95 & 75 & 4058 \\
\hline Croatia & 0.791 & 76 & 71.6 & 98 & 67 & 3972 \\
\hline Estonia & 0.790 & 77 & 69.2 & 99 & 72 & 4062 \\
\hline Iran, Islamic Rep. of & 0.790 & 77 & 68.5 & 69 & 67 & 5480 \\
\hline Lithuania & 0.781 & 79 & 70.2 & 99 & 70 & 3843 \\
\hline Macedonia, FYR & 0.780 & 80 & 71.9 & 94 & 60 & 4058 \\
\hline Syrian Arab Republic & 0.780 & 80 & 68.1 & 70.8 & 62 & 5374 \\
\hline Algeria & 0.777 & 82 & 68.1 & 61.6 & 66 & 5618 \\
\hline Tunisia & 0.775 & 83 & 68.7 & 66.7 & 69 & 5261 \\
\hline Jamaica & 0.766 & 84 & 74.1 & 85 & 67 & 3801 \\
\hline Cuba & 0.759 & 85 & 75.7 & 95.7 & 66 & 3100 \\
\hline Peru & 0.759 & 85 & 67.7 & 88.7 & 79 & 3940 \\
\hline Jordan & 0.759 & 85 & 68.9 & 86.6 & 66 & 4187 \\
\hline Dominican Republic & 0.750 & 88 & 70.3 & 82.1 & 73 & 3923 \\
\hline South Africa & 0.747 & 89 & 64.1 & 81.8 & 81 & 4334 \\
\hline Sri Lanka & 0.746 & 90 & 72.5 & 90.2 & 67 & 3408 \\
\hline Paraguay & 0.736 & 91 & 69.1 & 92.1 & 63 & 3583 \\
\hline Latvia & 0.733 & 92 & 68 & 99 & 67 & 3273 \\
\hline Kazakhstan & 0.724 & 93 & 67.5 & 99 & 73 & 3037 \\
\hline
\end{tabular}




\begin{tabular}{|c|c|c|c|c|c|c|}
\hline & $\begin{array}{c}\text { HDI } \\
\text { value }\end{array}$ & Rank & $\begin{array}{c}\text { Life } \\
\text { expectancy }\end{array}$ & $\begin{array}{c}\text { Adult } \\
\text { literacy }\end{array}$ & $\begin{array}{l}\text { Enrolment } \\
\text { ratio }\end{array}$ & $\begin{array}{c}\text { GDP } \\
\text { per capita }\end{array}$ \\
\hline Samoa (Western) & 0.723 & 94 & 68.4 & 98 & 74 & 2948 \\
\hline Maldives & 0.711 & 95 & 63.3 & 93.2 & 71 & 3540 \\
\hline Indonesia & 0.707 & 96 & 64 & 83.8 & 62 & 3971 \\
\hline Botswana & 0.706 & 97 & 51.7 & 69.8 & 71 & 5611 \\
\hline Philippines & 0.705 & 98 & 67.4 & 94.6 & 80 & 2762 \\
\hline Armenia & 0.702 & 99 & 70.9 & 98.8 & 78 & 2208 \\
\hline Guyana & 0.698 & 100 & 63.5 & 98.1 & 64 & 3205 \\
\hline Mongolia & 0.697 & 101 & 64.8 & 82.9 & 53 & 3916 \\
\hline Ukraine & 0.693 & 102 & 68.5 & 98 & 76 & 2361 \\
\hline Turkmenistan & 0.688 & 103 & 64.9 & 98 & 90 & 2345 \\
\hline Uzbekistan & 0.686 & 104 & 67.5 & 99 & 73 & 2376 \\
\hline Albania & 0.683 & 105 & 70.6 & 85 & 59 & 2853 \\
\hline China & 0.677 & 106 & 69.2 & 81.5 & 64 & 2935 \\
\hline Namibia & 0.671 & 107 & 55.8 & 76 & 83 & 4054 \\
\hline Georgia & 0.659 & 108 & 73.2 & 99 & 69 & 1389 \\
\hline Kyrgyzstan & 0.659 & 108 & 67.9 & 97 & 73 & 1927 \\
\hline Azerbaijan & 0.649 & 110 & 71.1 & 96.3 & 72 & 1463 \\
\hline Guatemala & 0.641 & 111 & 66.1 & 65 & 46 & 3682 \\
\hline Egypt & 0.638 & 112 & 64.8 & 51.4 & 69 & 3829 \\
\hline Moldova, Rep. of & 0.635 & 113 & 67.8 & 98.9 & 67 & 1547 \\
\hline El Salvador & 0.629 & 114 & 69.4 & 71.5 & 58 & 2610 \\
\hline$\overline{\text { Swaziland }}$ & 0.622 & 115 & 58.8 & 76.7 & 77 & 2954 \\
\hline Bolivia & 0.618 & 116 & 60.5 & 83.1 & 69 & 2617 \\
\hline Cape Verde & 0.616 & 117 & 65.7 & 71.6 & 64 & 2612 \\
\hline Tajikistan & 0.599 & 118 & 66.9 & 99 & 69 & 943 \\
\hline Honduras & 0.597 & 119 & 68.8 & 72.7 & 60 & 1977 \\
\hline Gabon & 0.592 & 120 & 54.5 & 63.2 & 60 & 3766 \\
\hline Sâo Tomé and Principe & 0.586 & 121 & 69 & 75 & 57 & 1744 \\
\hline Vietnam & 0.583 & 122 & 66.4 & 93.7 & 55 & 1236 \\
\hline Solomon Islands & 0.583 & 122 & 71.1 & 62 & 47 & 2230 \\
\hline Vanuatu & 0.582 & 124 & 66.3 & 64 & 52 & 2507 \\
\hline Morocco & 0.580 & 125 & 65.7 & 43.7 & 48 & 3477 \\
\hline Nicaragua & 0.570 & 126 & 67.5 & 65.7 & 64 & 1837 \\
\hline Iraq & 0.560 & 127 & 58.5 & 58 & 52 & 3170 \\
\hline Congo & 0.541 & 128 & 51.2 & 74.9 & 68 & 2554 \\
\hline Papua New Guinea & 0.528 & 129 & 56.8 & 72.2 & 37 & 2500 \\
\hline Zimbabwe & 0.528 & 129 & 48.9 & 85.1 & 69 & 2135 \\
\hline Myanmar & 0.501 & 131 & 58.9 & 83.1 & 48 & 1130 \\
\hline Cameroon & 0.501 & 131 & 55.3 & 63.4 & 45 & 2355 \\
\hline Ghana & 0.493 & 133 & 57 & 64.5 & 44 & 2032 \\
\hline Lesotho & 0.489 & 134 & 58.1 & 71.3 & 56 & 1290 \\
\hline Equatorial Guinea & 0.484 & 135 & 49 & 78.5 & 64 & 1712 \\
\hline Lao People's Dem. Rep. & 0.484 & 135 & 52.2 & 56.6 & 50 & 2571 \\
\hline Kenya & 0.482 & 137 & 53.8 & 78.1 & 52 & 1438 \\
\hline Pakistan & 0.472 & 138 & 62.8 & 37.8 & 41 & 2209 \\
\hline India & 0.470 & 139 & 61.6 & 52 & 55 & 1422 \\
\hline Cambodia & 0.440 & 140 & 52.9 & 65 & 62 & 1110 \\
\hline Comoros & 0.428 & 141 & 56.5 & 57.3 & 39 & 1317 \\
\hline
\end{tabular}




\begin{tabular}{|c|c|c|c|c|c|c|}
\hline & $\begin{array}{c}\text { HDI } \\
\text { value }\end{array}$ & Rank & $\begin{array}{c}\text { Life } \\
\text { expectancy }\end{array}$ & $\begin{array}{c}\text { Adult } \\
\text { literacy }\end{array}$ & $\begin{array}{c}\text { Enrolment } \\
\text { ratio }\end{array}$ & $\begin{array}{c}\text { GDP } \\
\text { per capita }\end{array}$ \\
\hline Nigeria & 0.407 & 142 & 51.4 & 57.1 & 49 & 1270 \\
\hline Dem. Rep. of the Congo & 0.399 & 143 & 52.4 & 77.3 & 41 & 355 \\
\hline Togo & 0.396 & 144 & 50.5 & 51.7 & 60 & 1167 \\
\hline Benin & 0.394 & 145 & 54.4 & 37 & 38 & 1800 \\
\hline Zambia & 0.394 & 145 & 42.7 & 78.2 & 52 & 986 \\
\hline Bangladesh & 0.386 & 147 & 56.9 & 38.1 & 37 & 1382 \\
\hline Côte d'Ivoire & 0.383 & 148 & 51.8 & 40.1 & 38 & 1731 \\
\hline Mauritania & 0.376 & 149 & 52.5 & 37.7 & 38 & 1622 \\
\hline Tanzania, U. Rep. of & 0.373 & 150 & 50.6 & 67.8 & 33 & 636 \\
\hline Yemen & 0.371 & 151 & 56.7 & 38 & 49 & 856 \\
\hline Nepal & 0.366 & 152 & 55.9 & 27.5 & 56 & 1145 \\
\hline Madagascar & 0.363 & 153 & 57.6 & 45.8 & 31 & 673 \\
\hline Central African Republic & 0.361 & 154 & 48.4 & 60 & 27 & 1092 \\
\hline Bhutan & 0.361 & 154 & 52 & 42.2 & 31 & 1382 \\
\hline Angola & 0.358 & 156 & 47.4 & 42 & 30 & 1839 \\
\hline Sudan & 0.357 & 157 & 52.2 & 46.1 & 32 & 1110 \\
\hline Senegal & 0.356 & 158 & 50.3 & 33.1 & 33 & 1815 \\
\hline Haiti & 0.354 & 159 & 54.6 & 45 & 29 & 917 \\
\hline Uganda & 0.354 & 159 & 40.5 & 61.8 & 38 & 1483 \\
\hline Malawi & 0.348 & 161 & 41 & 56.4 & 76 & 773 \\
\hline Djibouti & 0.338 & 162 & 49.2 & 46.2 & 20 & 1300 \\
\hline Chad & 0.331 & 163 & 47.2 & 48.1 & 27 & 1172 \\
\hline Guinea-Bissau & 0.307 & 164 & 43.4 & 54.9 & 29 & 811 \\
\hline Gambia & 0.303 & 165 & 46 & 38.6 & 39 & 948 \\
\hline Mozambique & 0.293 & 166 & 46.3 & 40.1 & 25 & 959 \\
\hline Guinea & 0.289 & 167 & 45.5 & 35.9 & 25 & 1139 \\
\hline Eritrea & 0.286 & 168 & 50.2 & 25 & 29 & 983 \\
\hline Ethiopia & 0.263 & 169 & 48.7 & 35.5 & 20 & 455 \\
\hline Burundi & 0.251 & 170 & 44.5 & 35.3 & 23 & 637 \\
\hline Mali & 0.246 & 171 & 47 & 31 & 18 & 565 \\
\hline Burkina Faso & 0.228 & 172 & 46.3 & 19.2 & 19 & 784 \\
\hline Niger & 0.216 & 173 & 47.5 & 13.6 & 15 & 765 \\
\hline Sierra Leone & 0.193 & 174 & 34.7 & 31.4 & 30 & 625 \\
\hline
\end{tabular}

Source: UNDP (1998). 
Table 9: Basic DEA results (ranks, scores transformed, weights).

\begin{tabular}{|c|c|c|c|c|c|c|}
\hline & $\begin{array}{l}\text { Index } \\
\text { value }\end{array}$ & Rank & $\begin{array}{c}\text { Weight of } \\
\text { life } \\
\text { expectancy }\end{array}$ & $\begin{array}{c}\text { Weight of } \\
\text { adult } \\
\text { literacy }\end{array}$ & $\begin{array}{c}\text { Weight of } \\
\text { enrolment } \\
\text { rate }\end{array}$ & $\begin{array}{c}\text { Weight of } \\
\text { GDP per } \\
\text { capita }\end{array}$ \\
\hline Australia & 1 & 1 & 0 & 1 & 0 & 0 \\
\hline Austria & 1 & 1 & 0 & 1 & 0 & 0 \\
\hline Belgium & 1 & 1 & 0 & 1 & 0 & 0 \\
\hline Brunei Darussalam & 1 & 1 & 0 & 0 & 0.31 & 0.69 \\
\hline Canada & 1 & 1 & 0.72 & 0 & 0.27 & 0.01 \\
\hline Czech Republic & 1 & 1 & 0 & 1 & 0 & 0 \\
\hline Denmark & 1 & 1 & 0 & 1 & 0 & 0 \\
\hline Estonia & 1 & 1 & 0 & 1 & 0 & 0 \\
\hline Finland & 1 & 1 & 0 & 1 & 0 & 0 \\
\hline France & 1 & 1 & 0 & 1 & 0 & 0 \\
\hline Georgia & 1 & 1 & 0 & 1 & 0 & 0 \\
\hline Germany & 1 & 1 & 0 & 1 & 0 & 0 \\
\hline Hungary & 1 & 1 & 0 & 1 & 0 & 0 \\
\hline Iceland & 1 & 1 & 0 & 1 & 0 & 0 \\
\hline Ireland & 1 & 1 & 0 & 1 & 0 & 0 \\
\hline Japan & 1 & 1 & 0.97 & 0 & 0 & 0.03 \\
\hline Kazakhstan & 1 & 1 & 0 & 1 & 0 & 0 \\
\hline Latvia & 1 & 1 & 0 & 1 & 0 & 0 \\
\hline Lithuania & 1 & 1 & 0 & 1 & 0 & 0 \\
\hline Luxembourg & 1 & 1 & 0 & 0.53 & 0 & 0.47 \\
\hline Netherlands & 1 & 1 & 0 & 1 & 0 & 0 \\
\hline New Zealand & 1 & 1 & 0 & 1 & 0 & 0 \\
\hline Norway & 1 & 1 & 0 & 1 & 0 & 0 \\
\hline Poland & 1 & 1 & 0 & 1 & 0 & 0 \\
\hline Russian Federation & 1 & 1 & 0 & 1 & 0 & 0 \\
\hline Slovakia & 1 & 1 & 0 & 1 & 0 & 0 \\
\hline Sweden & 1 & 1 & 0 & 1 & 0 & 0 \\
\hline Switzerland & 1 & 1 & 0 & 1 & 0 & 0 \\
\hline Tajikistan & 1 & 1 & 0 & 1 & 0 & 0 \\
\hline United Kingdom & 1 & 1 & 0 & 1 & 0 & 0 \\
\hline USA & 1 & 1 & 0 & 0 & 0.56 & 0.44 \\
\hline Uzbekistan & 1 & 1 & 0 & 1 & 0 & 0 \\
\hline Moldova, Rep. of & 0.999 & 33 & 0 & 1 & 0 & 0 \\
\hline Armenia & 0.998 & 34 & 0 & 1 & 0 & 0 \\
\hline Hong Kong, China & 0.993 & 35 & 0.92 & 0 & 0 & 0.08 \\
\hline Bahamas & 0.992 & 36 & 0 & 1 & 0 & 0 \\
\hline Italy & 0.991 & 37 & 0 & 1 & 0 & 0 \\
\hline Guyana & 0.991 & 37 & 0 & 1 & 0 & 0 \\
\hline Korea, Rep. of & 0.990 & 39 & 0 & 1 & 0 & 0 \\
\hline Grenada & 0.990 & 39 & 0 & 1 & 0 & 0 \\
\hline Bulgaria & 0.990 & 39 & 0 & 1 & 0 & 0 \\
\hline Turkmenistan & 0.990 & 39 & 0 & 1 & 0 & 0 \\
\hline Croatia & 0.990 & 39 & 0 & 1 & 0 & 0 \\
\hline Romania & 0.990 & 39 & 0 & 1 & 0 & 0 \\
\hline Samoa (Western) & 0.990 & 39 & 0 & 1 & 0 & 0 \\
\hline Ukraine & 0.990 & 39 & 0 & 1 & 0 & 0 \\
\hline
\end{tabular}




\begin{tabular}{|c|c|c|c|c|c|c|}
\hline & $\begin{array}{l}\text { Index } \\
\text { value }\end{array}$ & Rank & $\begin{array}{l}\text { Weight of } \\
\text { life } \\
\text { expectancy }\end{array}$ & $\begin{array}{l}\text { Weight of } \\
\text { adult } \\
\text { literacy }\end{array}$ & $\begin{array}{c}\text { Weight of } \\
\text { enrolment } \\
\text { rate }\end{array}$ & $\begin{array}{c}\text { Weight of } \\
\text { GDP per } \\
\text { capita }\end{array}$ \\
\hline Trinidad and Tobago & 0.989 & 47 & 0 & 1 & 0 & 0 \\
\hline Belarus & 0.989 & 47 & 0 & 1 & 0 & 0 \\
\hline Barbados & 0.984 & 49 & 0 & 1 & 0 & 0 \\
\hline Uruguay & 0.983 & 50 & 0 & 1 & 0 & 0 \\
\hline Spain & 0.981 & 51 & 0 & 1 & 0 & 0 \\
\hline Kyrgyzstan & 0.980 & 52 & 0 & 1 & 0 & 0 \\
\hline Greece & 0.978 & 53 & 0.96 & 0 & 0.04 & 0 \\
\hline Azerbaijan & 0.973 & 54 & 0 & 1 & 0 & 0 \\
\hline Argentina & 0.972 & 55 & 0 & 1 & 0 & 0 \\
\hline Singapore & 0.970 & 56 & 0.92 & 0 & 0 & 0.08 \\
\hline Israel & 0.970 & 57 & 1 & 0 & 0 & 0 \\
\hline Slovenia & 0.970 & 58 & 0 & 1 & 0 & 0 \\
\hline Cyprus & 0.968 & 59 & 0.96 & 0 & 0.04 & 0 \\
\hline Cuba & 0.967 & 60 & 0 & 1 & 0 & 0 \\
\hline Chile & 0.962 & 61 & 0 & 1 & 0 & 0 \\
\hline Antigua and Barbuda & 0.960 & 62 & 0 & 1 & 0 & 0 \\
\hline Korea, Dem. People's Rep. of & 0.960 & 62 & 0 & 1 & 0 & 0 \\
\hline Costa Rica & 0.959 & 64 & 1 & 0 & 0 & 0 \\
\hline Malta & 0.958 & 65 & 0.97 & 0 & 0.03 & 0 \\
\hline Philippines & 0.956 & 66 & 0 & 1 & 0 & 0 \\
\hline Kuwait & 0.955 & 67 & 0.91 & 0 & 0 & 0.09 \\
\hline Dominica & 0.949 & 68 & 0 & 1 & 0 & 0 \\
\hline Macedonia, FYR & 0.949 & 68 & 0 & 1 & 0 & 0 \\
\hline Thailand & 0.948 & 70 & 0 & 1 & 0 & 0 \\
\hline Vietnam & 0.946 & 71 & 0 & 1 & 0 & 0 \\
\hline Maldives & 0.941 & 72 & 0 & 1 & 0 & 0 \\
\hline Portugal & 0.940 & 73 & 0.96 & 0 & 0.04 & 0 \\
\hline Suriname & 0.939 & 74 & 0 & 1 & 0 & 0 \\
\hline Lebanon & 0.933 & 75 & 0 & 1 & 0 & 0 \\
\hline United Arab Emirates & 0.931 & 76 & 1 & 0 & 0 & 0 \\
\hline Paraguay & 0.930 & 77 & 0 & 1 & 0 & 0 \\
\hline Belize & 0.929 & 78 & 0.97 & 0 & 0.03 & 0 \\
\hline Jamaica & 0.927 & 79 & 1 & 0 & 0 & 0 \\
\hline Fiji & 0.925 & 80 & 0 & 1 & 0 & 0 \\
\hline Colombia & 0.922 & 81 & 0 & 1 & 0 & 0 \\
\hline Venezuela & 0.920 & 82 & 0 & 1 & 0 & 0 \\
\hline Panama & 0.919 & 83 & 0.97 & 0 & 0.03 & 0 \\
\hline Sri Lanka & 0.911 & 84 & 0 & 1 & 0 & 0 \\
\hline Ecuador & 0.910 & 85 & 0 & 1 & 0 & 0 \\
\hline Bahrain & 0.910 & 86 & 0.96 & 0 & 0.04 & 0 \\
\hline Saint Kitts and Nevis & 0.909 & 87 & 0 & 1 & 0 & 0 \\
\hline Mexico & 0.905 & 88 & 0 & 1 & 0 & 0 \\
\hline Saint Vincent & 0.904 & 89 & 0.96 & 0 & 0.04 & 0 \\
\hline Seychelles & 0.901 & 90 & 1 & 0 & 0 & 0 \\
\hline Libyan Arab Jamahiriya & 0.900 & 91 & 0 & 0 & 1 & 0 \\
\hline Peru & 0.896 & 92 & 0 & 1 & 0 & 0 \\
\hline Malaysia & 0.894 & 93 & 1 & 0 & 0 & 0 \\
\hline Qatar & 0.892 & 94 & 0.88 & 0 & 0.03 & 0.09 \\
\hline
\end{tabular}




\begin{tabular}{|c|c|c|c|c|c|c|}
\hline & $\begin{array}{l}\text { Index } \\
\text { value }\end{array}$ & Rank & $\begin{array}{l}\text { Weight of } \\
\text { life } \\
\text { expectancy }\end{array}$ & $\begin{array}{l}\text { Weight of } \\
\text { adult } \\
\text { literacy }\end{array}$ & $\begin{array}{c}\text { Weight of } \\
\text { enrolment } \\
\text { rate }\end{array}$ & $\begin{array}{c}\text { Weight of } \\
\text { GDP per } \\
\text { capita }\end{array}$ \\
\hline $\begin{array}{l}\text { Saint Lucia } \\
\text { sing }\end{array}$ & 0.891 & 95 & 0.96 & 0 & 0.04 & 0 \\
\hline Solomon Islands & 0.890 & 96 & 1 & 0 & 0 & 0 \\
\hline Mauritius & 0.887 & 97 & 1 & 0 & 0 & 0 \\
\hline Saudi Arabia & 0.885 & 98 & 1 & 0 & 0 & 0 \\
\hline Albania & 0.884 & 99 & 1 & 0 & 0 & 0 \\
\hline Dominican Republic & 0.882 & 100 & 0.96 & 0 & 0.04 & 0 \\
\hline Oman & 0.880 & 101 & 1 & 0 & 0 & 0 \\
\hline Jordan & 0.875 & 102 & 0 & 1 & 0 & 0 \\
\hline El Salvador & 0.869 & 103 & 1 & 0 & 0 & 0 \\
\hline China & 0.866 & 104 & 1 & 0 & 0 & 0 \\
\hline Sâo Tomé and Principe & 0.864 & 105 & 1 & 0 & 0 & 0 \\
\hline Honduras & 0.861 & 106 & 1 & 0 & 0 & 0 \\
\hline Tunisia & 0.861 & 107 & 0.96 & 0 & 0.04 & 0 \\
\hline Zimbabwe & 0.860 & 108 & 0 & 1 & 0 & 0 \\
\hline Iran, Islamic Rep. of & 0.857 & 109 & 0.97 & 0 & 0.03 & 0 \\
\hline Turkey & 0.857 & 110 & 1 & 0 & 0 & 0 \\
\hline Syrian Arab Republic & 0.852 & 111 & 1 & 0 & 0 & 0 \\
\hline Algeria & 0.852 & 111 & 1 & 0 & 0 & 0 \\
\hline Indonesia & 0.846 & 113 & 0 & 1 & 0 & 0 \\
\hline Nicaragua & 0.845 & 114 & 1 & 0 & 0 & 0 \\
\hline Brazil & 0.841 & 115 & 0 & 1 & 0 & 0 \\
\hline Bolivia & 0.839 & 116 & 0 & 1 & 0 & 0 \\
\hline Myanmar & 0.839 & 116 & 0 & 1 & 0 & 0 \\
\hline Mongolia & 0.837 & 118 & 0 & 1 & 0 & 0 \\
\hline Namibia & 0.830 & 119 & 0 & 0 & 1 & 0 \\
\hline Vanuatu & 0.830 & 120 & 1 & 0 & 0 & 0 \\
\hline Guatemala & 0.827 & 121 & 1 & 0 & 0 & 0 \\
\hline South Africa & 0.826 & 122 & 0 & 1 & 0 & 0 \\
\hline Cape Verde & 0.822 & 123 & 1 & 0 & 0 & 0 \\
\hline Morocco & 0.822 & 123 & 1 & 0 & 0 & 0 \\
\hline Egypt & 0.814 & 125 & 0.96 & 0 & 0.04 & 0 \\
\hline Equatorial Guinea & 0.793 & 126 & 0 & 1 & 0 & 0 \\
\hline Zambia & 0.790 & 127 & 0 & 1 & 0 & 0 \\
\hline Kenya & 0.789 & 128 & 0 & 1 & 0 & 0 \\
\hline Pakistan & 0.786 & 129 & 1 & 0 & 0 & 0 \\
\hline Dem. Rep. of the Congo & 0.781 & 130 & 0 & 1 & 0 & 0 \\
\hline Swaziland & 0.775 & 131 & 0 & 1 & 0 & 0 \\
\hline India & 0.771 & 132 & 1 & 0 & 0 & 0 \\
\hline Malawi & 0.760 & 133 & 0 & 0 & 1 & 0 \\
\hline Congo & 0.757 & 134 & 0 & 1 & 0 & 0 \\
\hline Iraq & 0.732 & 135 & 1 & 0 & 0 & 0 \\
\hline Papua New Guinea & 0.729 & 136 & 0 & 1 & 0 & 0 \\
\hline Lesotho & 0.727 & 137 & 1 & 0 & 0 & 0 \\
\hline Madagascar & 0.721 & 138 & 1 & 0 & 0 & 0 \\
\hline Ghana & 0.713 & 139 & 1 & 0 & 0 & 0 \\
\hline Bangladesh & 0.712 & 140 & 1 & 0 & 0 & 0 \\
\hline Botswana & 0.710 & 141 & 0 & 0 & 1 & 0 \\
\hline Yemen & 0.710 & 142 & 1 & 0 & 0 & 0 \\
\hline
\end{tabular}




\begin{tabular}{lcccccc}
\hline & $\begin{array}{c}\text { Index } \\
\text { value }\end{array}$ & Rank & $\begin{array}{c}\text { Weight of } \\
\text { life } \\
\text { expectancy }\end{array}$ & $\begin{array}{c}\text { Weight of } \\
\text { adult } \\
\text { literacy }\end{array}$ & $\begin{array}{c}\text { Weight of } \\
\text { enrolment } \\
\text { rate }\end{array}$ & $\begin{array}{c}\text { Weight of } \\
\text { GDP per } \\
\text { capita }\end{array}$ \\
\hline Comoros & 0.707 & 143 & 1 & 0 & 0 & 0 \\
\hline Nepal & 0.700 & 144 & 0.96 & 0 & 0.04 & 0 \\
\hline Cameroon & 0.692 & 145 & 1 & 0 & 0 & 0 \\
\hline Gabon & 0.685 & 146 & 0.96 & 0 & 0.04 & 0 \\
\hline Tanzania, U. Rep. of & 0.685 & 147 & 0 & 1 & 0 & 0 \\
\hline Haiti & 0.683 & 148 & 1 & 0 & 0 & 0 \\
\hline Benin & 0.681 & 149 & 1 & 0 & 0 & 0 \\
\hline Cambodia & 0.667 & 150 & 0.96 & 0 & 0.04 & 0 \\
\hline Mauritania & 0.657 & 151 & 1 & 0 & 0 & 0 \\
\hline Lao People's Dem. Rep. & 0.653 & 152 & 1 & 0 & 0 & 0 \\
\hline Sudan & 0.653 & 152 & 1 & 0 & 0 & 0 \\
\hline Bhutan & 0.651 & 154 & 1 & 0 & 0 & 0 \\
\hline Côte d'Ivoire & 0.648 & 155 & 1 & 0 & 0 & 0 \\
\hline Nigeria & 0.643 & 156 & 1 & 0 & 0 & 0 \\
\hline Togo & 0.637 & 157 & 0.96 & 0 & 0.04 & 0 \\
\hline Senegal & 0.630 & 158 & 1 & 0 & 0 & 0 \\
\hline Eritrea & 0.628 & 159 & 1 & 0 & 0 & 0 \\
\hline Uganda & 0.624 & 160 & 0 & 1 & 0 & 0 \\
\hline Djibouti & 0.616 & 161 & 1 & 0 & 0 & 0 \\
\hline Ethiopia & 0.609 & 162 & 1 & 0 & 0 & 0 \\
\hline Central African Republic & 0.606 & 163 & 0 & 1 & 0 & 0 \\
\hline Niger & 0.594 & 164 & 1 & 0 & 0 & 0 \\
\hline Angola & 0.593 & 165 & 1 & 0 & 0 & 0 \\
\hline Chad & 0.591 & 166 & 1 & 0 & 0 & 0 \\
\hline Mali & 0.588 & 167 & 1 & 0 & 0 & 0 \\
\hline Mozambique & 0.579 & 168 & 1 & 0 & 0 & 0 \\
\hline Burkina Faso & 0.579 & 168 & 1 & 0 & 0 & 0 \\
\hline Gambia & 0.576 & 170 & 1 & 0 & 0 & 0 \\
\hline Guinea & 0.569 & 171 & 1 & 0 & 0 & 0 \\
\hline Burundi & 0.557 & 172 & 1 & 0 & 0 & 0 \\
\hline Guinea-Bissau & 0.555 & 173 & 0 & 1 & 0 & 0 \\
\hline Sierra Leone & 0.434 & 174 & 1 & 0 & 0 & 0 \\
\hline Source: Owa & & & 0 & & \\
\hline
\end{tabular}

Source: Own computations based on UNDP (1998). 
Table 10: Results of the DEA model with weight restrictions (ranks, scores transformed, weights).

\begin{tabular}{|c|c|c|c|c|c|c|}
\hline & $\begin{array}{l}\text { Index } \\
\text { value }\end{array}$ & Rank & $\begin{array}{l}\text { Weight of } \\
\text { life } \\
\text { expectancy }\end{array}$ & $\begin{array}{l}\text { Weight of } \\
\text { adult } \\
\text { literacy }\end{array}$ & $\begin{array}{c}\text { Weight of } \\
\text { enrolment } \\
\text { rate }\end{array}$ & $\begin{array}{c}\text { Weight of } \\
\text { GDP per } \\
\text { capita }\end{array}$ \\
\hline Luxembourg & 1 & 1 & 0.002 & 0.225 & 0.001 & 0.772 \\
\hline Brunei Darussalam & 0.972 & 2 & 0.163 & 0.002 & 0.160 & 0.675 \\
\hline USA & 0.944 & 3 & 0.141 & 0.183 & 0.177 & 0.499 \\
\hline Switzerland & 0.876 & 4 & 0.156 & 0.197 & 0.151 & 0.496 \\
\hline Canada & 0.868 & 5 & 0.159 & 0.199 & 0.201 & 0.441 \\
\hline Norway & 0.860 & 6 & 0.157 & 0.201 & 0.187 & 0.455 \\
\hline Denmark & 0.843 & 7 & 0.156 & 0.205 & 0.184 & 0.455 \\
\hline France & 0.835 & 8 & 0.165 & 0.207 & 0.186 & 0.443 \\
\hline Belgium & 0.833 & 9 & 0.161 & 0.207 & 0.180 & 0.451 \\
\hline Japan & 0.831 & 10 & 0.168 & 0.208 & 0.164 & 0.461 \\
\hline Austria & 0.830 & 11 & 0.161 & 0.208 & 0.183 & 0.448 \\
\hline Iceland & 0.823 & 12 & 0.168 & 0.210 & 0.176 & 0.446 \\
\hline Hong Kong, China & 0.816 & 13 & 0.169 & 0.197 & 0.143 & 0.491 \\
\hline Netherlands & 0.814 & 14 & 0.166 & 0.212 & 0.195 & 0.426 \\
\hline Singapore & 0.807 & 15 & 0.167 & 0.197 & 0.147 & 0.489 \\
\hline Germany & 0.803 & 16 & 0.166 & 0.215 & 0.176 & 0.443 \\
\hline Finland & 0.799 & 17 & 0.167 & 0.216 & 0.212 & 0.405 \\
\hline United Kingdom & 0.794 & 18 & 0.169 & 0.218 & 0.189 & 0.424 \\
\hline Australia & 0.790 & 19 & 0.173 & 0.219 & 0.175 & 0.434 \\
\hline Sweden & 0.789 & 20 & 0.173 & 0.219 & 0.181 & 0.427 \\
\hline Italy & 0.787 & 21 & 0.173 & 0.218 & 0.162 & 0.448 \\
\hline Kuwait & 0.786 & 22 & 0.167 & 0.175 & 0.129 & 0.529 \\
\hline New Zealand & 0.772 & 23 & 0.173 & 0.224 & 0.213 & 0.390 \\
\hline Ireland & 0.766 & 24 & 0.174 & 0.225 & 0.200 & 0.400 \\
\hline Qatar & 0.731 & 25 & 0.170 & 0.189 & 0.169 & 0.472 \\
\hline Israel & 0.723 & 26 & 0.187 & 0.229 & 0.181 & 0.403 \\
\hline Spain & 0.720 & 27 & 0.188 & 0.235 & 0.218 & 0.358 \\
\hline Bahrain & 0.713 & 28 & 0.177 & 0.208 & 0.205 & 0.410 \\
\hline United Arab Emirates & 0.703 & 29 & 0.185 & 0.197 & 0.171 & 0.447 \\
\hline Bahamas & 0.699 & 30 & 0.183 & 0.245 & 0.180 & 0.393 \\
\hline Cyprus & 0.670 & 31 & 0.201 & 0.245 & 0.206 & 0.348 \\
\hline Malta & 0.657 & 32 & 0.203 & 0.242 & 0.202 & 0.354 \\
\hline Greece & 0.651 & 33 & 0.209 & 0.259 & 0.220 & 0.312 \\
\hline Portugal & 0.649 & 34 & 0.201 & 0.241 & 0.218 & 0.341 \\
\hline Korea, Rep. of & 0.643 & 35 & 0.195 & 0.266 & 0.225 & 0.315 \\
\hline Barbados & 0.634 & 36 & 0.209 & 0.268 & 0.212 & 0.311 \\
\hline Slovenia & 0.609 & 37 & 0.210 & 0.275 & 0.212 & 0.303 \\
\hline Mauritius & 0.607 & 38 & 0.204 & 0.238 & 0.175 & 0.382 \\
\hline Chile & 0.598 & 39 & 0.219 & 0.278 & 0.213 & 0.290 \\
\hline Czech Republic & 0.592 & 40 & 0.214 & 0.292 & 0.206 & 0.288 \\
\hline Saint Kitts and Nevis & 0.591 & 41 & 0.204 & 0.266 & 0.230 & 0.300 \\
\hline Antigua and Barbuda & 0.589 & 42 & 0.222 & 0.282 & 0.225 & 0.271 \\
\hline Argentina & 0.581 & 43 & 0.218 & 0.289 & 0.237 & 0.255 \\
\hline Trinidad and Tobago & 0.576 & 44 & 0.221 & 0.296 & 0.197 & 0.286 \\
\hline Slovakia & 0.550 & 45 & 0.225 & 0.314 & 0.229 & 0.232 \\
\hline
\end{tabular}




\begin{tabular}{|c|c|c|c|c|c|c|}
\hline & $\begin{array}{l}\text { Index } \\
\text { value }\end{array}$ & Rank & $\begin{array}{l}\text { Weight of } \\
\text { life } \\
\text { expectancy }\end{array}$ & $\begin{array}{l}\text { Weight of } \\
\text { adult } \\
\text { literacy }\end{array}$ & $\begin{array}{c}\text { Weight of } \\
\text { enrolment } \\
\text { rate }\end{array}$ & $\begin{array}{c}\text { Weight of } \\
\text { GDP per } \\
\text { capita }\end{array}$ \\
\hline $\begin{array}{l}\text { Uruguay } \\
\end{array}$ & 0.549 & 46 & 0.231 & 0.309 & 0.242 & 0.218 \\
\hline Malaysia & 0.544 & 47 & 0.229 & 0.268 & 0.196 & 0.307 \\
\hline Venezuela & 0.543 & 48 & 0.232 & 0.293 & 0.215 & 0.260 \\
\hline Dominica & 0.538 & 49 & 0.237 & 0.305 & 0.250 & 0.208 \\
\hline Poland & 0.530 & 50 & 0.234 & 0.326 & 0.260 & 0.179 \\
\hline Fiji & 0.529 & 51 & 0.238 & 0.302 & 0.257 & 0.203 \\
\hline Hungary & 0.528 & 52 & 0.228 & 0.327 & 0.221 & 0.224 \\
\hline Grenada & 0.527 & 53 & 0.238 & 0.324 & 0.258 & 0.180 \\
\hline Costa Rica & 0.524 & 54 & 0.255 & 0.316 & 0.230 & 0.199 \\
\hline Panama & 0.521 & 55 & 0.246 & 0.304 & 0.241 & 0.210 \\
\hline Seychelles & 0.520 & 56 & 0.242 & 0.295 & 0.205 & 0.258 \\
\hline Mexico & 0.517 & 57 & 0.243 & 0.302 & 0.226 & 0.228 \\
\hline Thailand & 0.516 & 58 & 0.235 & 0.317 & 0.186 & 0.262 \\
\hline Colombia & 0.513 & 59 & 0.239 & 0.311 & 0.235 & 0.216 \\
\hline Libyan Arab Jamahiriya & 0.512 & 60 & 0.219 & 0.260 & 0.307 & 0.215 \\
\hline Saint Lucia & 0.510 & 61 & 0.243 & 0.281 & 0.253 & 0.223 \\
\hline Saint Vincent & 0.509 & 62 & 0.247 & 0.281 & 0.267 & 0.205 \\
\hline Belarus & 0.508 & 63 & 0.238 & 0.336 & 0.275 & 0.151 \\
\hline Russian Federation & 0.502 & 64 & 0.228 & 0.344 & 0.271 & 0.157 \\
\hline Lebanon & 0.500 & 65 & 0.242 & 0.323 & 0.262 & 0.174 \\
\hline Suriname & 0.495 & 66 & 0.250 & 0.328 & 0.250 & 0.172 \\
\hline Oman & 0.494 & 67 & 0.248 & 0.208 & 0.212 & 0.331 \\
\hline Korea, Dem. People's Rep. of & 0.492 & 68 & 0.254 & 0.337 & 0.266 & 0.144 \\
\hline Bulgaria & 0.491 & 69 & 0.253 & 0.349 & 0.235 & 0.164 \\
\hline Brazil & 0.491 & 70 & 0.237 & 0.296 & 0.256 & 0.211 \\
\hline Estonia & 0.490 & 71 & 0.246 & 0.353 & 0.256 & 0.145 \\
\hline Lithuania & 0.484 & 72 & 0.253 & 0.357 & 0.252 & 0.138 \\
\hline Ecuador & 0.483 & 73 & 0.251 & 0.326 & 0.257 & 0.166 \\
\hline Turkmenistan & 0.482 & 74 & 0.235 & 0.355 & 0.326 & 0.085 \\
\hline Croatia & 0.482 & 75 & 0.259 & 0.355 & 0.243 & 0.144 \\
\hline Saudi Arabia & 0.481 & 76 & 0.256 & 0.228 & 0.207 & 0.309 \\
\hline Peru & 0.479 & 77 & 0.246 & 0.323 & 0.288 & 0.143 \\
\hline Belize & 0.479 & 78 & 0.270 & 0.255 & 0.270 & 0.205 \\
\hline Romania & 0.478 & 79 & 0.254 & 0.358 & 0.226 & 0.162 \\
\hline South Africa & 0.471 & 80 & 0.237 & 0.303 & 0.300 & 0.160 \\
\hline Samoa (Western) & 0.471 & 81 & 0.253 & 0.363 & 0.274 & 0.109 \\
\hline Kazakhstan & 0.471 & 82 & 0.250 & 0.367 & 0.271 & 0.113 \\
\hline Armenia & 0.471 & 83 & 0.263 & 0.366 & 0.289 & 0.082 \\
\hline Philippines & 0.470 & 84 & 0.250 & 0.351 & 0.297 & 0.102 \\
\hline Cuba & 0.468 & 85 & 0.282 & 0.357 & 0.246 & 0.116 \\
\hline Latvia & 0.465 & 86 & 0.255 & 0.371 & 0.251 & 0.123 \\
\hline Macedonia, FYR & 0.465 & 87 & 0.270 & 0.353 & 0.225 & 0.152 \\
\hline Ukraine & 0.464 & 88 & 0.257 & 0.368 & 0.286 & 0.089 \\
\hline Turkey & 0.464 & 89 & 0.258 & 0.309 & 0.226 & 0.207 \\
\hline Dominican Republic & 0.462 & 90 & 0.266 & 0.310 & 0.276 & 0.148 \\
\hline Jamaica & 0.461 & 91 & 0.281 & 0.322 & 0.254 & 0.144 \\
\hline Sri Lanka & 0.460 & 92 & 0.275 & 0.342 & 0.254 & 0.129 \\
\hline Jordan & 0.460 & 93 & 0.262 & 0.329 & 0.251 & 0.159 \\
\hline
\end{tabular}




\begin{tabular}{|c|c|c|c|c|c|c|}
\hline & $\begin{array}{l}\text { Index } \\
\text { value }\end{array}$ & Rank & $\begin{array}{l}\text { Weight of } \\
\text { life } \\
\text { expectancy }\end{array}$ & $\begin{array}{l}\text { Weight of } \\
\text { adult } \\
\text { literacy }\end{array}$ & $\begin{array}{c}\text { Weight of } \\
\text { enrolment } \\
\text { rate }\end{array}$ & $\begin{array}{c}\text { Weight of } \\
\text { GDP per } \\
\text { capita }\end{array}$ \\
\hline Uzbekistan & 0.459 & 94 & 0.256 & 0.376 & 0.277 & 0.090 \\
\hline Maldives & 0.459 & 95 & 0.241 & 0.355 & 0.270 & 0.135 \\
\hline Paraguay & 0.454 & 96 & 0.266 & 0.354 & 0.242 & 0.138 \\
\hline Iran, Islamic Rep. of & 0.452 & 97 & 0.264 & 0.266 & 0.258 & 0.211 \\
\hline Guyana & 0.450 & 98 & 0.247 & 0.381 & 0.248 & 0.124 \\
\hline Kyrgyzstan & 0.449 & 99 & 0.264 & 0.377 & 0.284 & 0.075 \\
\hline Tunisia & 0.448 & 100 & 0.267 & 0.260 & 0.269 & 0.205 \\
\hline Namibia & 0.446 & 101 & 0.219 & 0.298 & 0.325 & 0.159 \\
\hline Georgia & 0.445 & 102 & 0.287 & 0.388 & 0.271 & 0.055 \\
\hline Syrian Arab Republic & 0.444 & 103 & 0.267 & 0.278 & 0.244 & 0.211 \\
\hline Azerbaijan & 0.443 & 104 & 0.280 & 0.379 & 0.283 & 0.058 \\
\hline Algeria & 0.439 & 105 & 0.270 & 0.245 & 0.262 & 0.223 \\
\hline Indonesia & 0.435 & 106 & 0.257 & 0.336 & 0.249 & 0.159 \\
\hline Moldova, Rep. of & 0.435 & 107 & 0.272 & 0.397 & 0.269 & 0.062 \\
\hline Botswana & 0.434 & 108 & 0.208 & 0.281 & 0.286 & 0.226 \\
\hline Tajikistan & 0.426 & 109 & 0.274 & 0.405 & 0.282 & 0.039 \\
\hline China & 0.426 & 110 & 0.284 & 0.334 & 0.262 & 0.120 \\
\hline Albania & 0.424 & 111 & 0.290 & 0.350 & 0.243 & 0.117 \\
\hline Swaziland & 0.422 & 112 & 0.243 & 0.317 & 0.318 & 0.122 \\
\hline Mongolia & 0.418 & 113 & 0.270 & 0.346 & 0.221 & 0.163 \\
\hline Bolivia & 0.417 & 114 & 0.253 & 0.348 & 0.289 & 0.110 \\
\hline Vietnam & 0.397 & 115 & 0.292 & 0.412 & 0.242 & 0.054 \\
\hline Cape Verde & 0.397 & 116 & 0.289 & 0.315 & 0.281 & 0.115 \\
\hline El Salvador & 0.393 & 117 & 0.308 & 0.318 & 0.258 & 0.116 \\
\hline$\overline{\text { Zimbabwe }}$ & 0.391 & 118 & 0.218 & 0.379 & 0.308 & 0.095 \\
\hline Egypt & 0.390 & 119 & 0.290 & 0.230 & 0.309 & 0.171 \\
\hline Honduras & 0.386 & 120 & 0.311 & 0.329 & 0.271 & 0.089 \\
\hline Congo & 0.383 & 121 & 0.233 & 0.341 & 0.310 & 0.116 \\
\hline Sâo Tomé and Principe & 0.381 & 122 & 0.316 & 0.343 & 0.261 & 0.080 \\
\hline Nicaragua & 0.376 & 123 & 0.313 & 0.305 & 0.297 & 0.085 \\
\hline Gabon & 0.376 & 124 & 0.253 & 0.294 & 0.279 & 0.175 \\
\hline Guatemala & 0.373 & 125 & 0.309 & 0.304 & 0.215 & 0.172 \\
\hline Equatorial Guinea & 0.364 & 126 & 0.235 & 0.376 & 0.307 & 0.082 \\
\hline Vanuatu & 0.362 & 127 & 0.320 & 0.309 & 0.251 & 0.121 \\
\hline Solomon Islands & 0.353 & 128 & 0.351 & 0.306 & 0.232 & 0.110 \\
\hline Myanmar & 0.351 & 129 & 0.293 & 0.413 & 0.239 & 0.056 \\
\hline Iraq & 0.349 & 130 & 0.292 & 0.290 & 0.260 & 0.158 \\
\hline Lesotho & 0.346 & 131 & 0.293 & 0.360 & 0.282 & 0.065 \\
\hline Kenya & 0.346 & 132 & 0.271 & 0.394 & 0.262 & 0.073 \\
\hline Morocco & 0.335 & 133 & 0.342 & 0.227 & 0.250 & 0.181 \\
\hline Papua New Guinea & 0.333 & 134 & 0.297 & 0.378 & 0.194 & 0.131 \\
\hline Cambodia & 0.333 & 134 & 0.277 & 0.340 & 0.325 & 0.058 \\
\hline Cameroon & 0.327 & 136 & 0.295 & 0.339 & 0.240 & 0.126 \\
\hline Ghana & 0.324 & 137 & 0.307 & 0.347 & 0.237 & 0.109 \\
\hline Lao People"s Dem. Rep. & 0.322 & 138 & 0.283 & 0.307 & 0.271 & 0.139 \\
\hline India & 0.319 & 139 & 0.337 & 0.284 & 0.301 & 0.078 \\
\hline$\overline{\text { Zambia }}$ & 0.319 & 140 & 0.234 & 0.428 & 0.285 & 0.054 \\
\hline Malawi & 0.316 & 141 & 0.226 & 0.311 & 0.420 & 0.043 \\
\hline
\end{tabular}




\begin{tabular}{lcccccc}
\hline & $\begin{array}{c}\text { Index } \\
\text { value }\end{array}$ & Rank & $\begin{array}{c}\text { Weight of } \\
\text { life } \\
\text { expectancy }\end{array}$ & $\begin{array}{c}\text { Weight of } \\
\text { adult } \\
\text { literacy }\end{array}$ & $\begin{array}{c}\text { Weight of } \\
\text { enrolment } \\
\text { rate }\end{array}$ & $\begin{array}{c}\text { Weight of } \\
\text { GDP per } \\
\text { capita }\end{array}$ \\
\hline Dem. Rep. of the Congo & 0.304 & 142 & 0.301 & 0.444 & 0.235 & 0.020 \\
\hline Togo & 0.303 & 143 & 0.290 & 0.297 & 0.345 & 0.067 \\
\hline Nigeria & 0.297 & 144 & 0.302 & 0.336 & 0.288 & 0.075 \\
\hline Comoros & 0.290 & 145 & 0.340 & 0.345 & 0.235 & 0.079 \\
\hline Pakistan & 0.286 & 146 & 0.384 & 0.231 & 0.251 & 0.135 \\
\hline Tanzania, U. Rep. of & 0.275 & 147 & 0.321 & 0.430 & 0.209 & 0.040 \\
\hline Uganda & 0.271 & 148 & 0.261 & 0.398 & 0.245 & 0.096 \\
\hline Yemen & 0.266 & 149 & 0.372 & 0.250 & 0.322 & 0.056 \\
\hline Nepal & 0.263 & 150 & 0.371 & 0.182 & 0.371 & 0.076 \\
\hline Benin & 0.257 & 151 & 0.369 & 0.251 & 0.258 & 0.122 \\
\hline Côte d'Ivoire & 0.257 & 152 & 0.352 & 0.272 & 0.258 & 0.118 \\
\hline Central African Republic & 0.255 & 153 & 0.331 & 0.410 & 0.185 & 0.075 \\
\hline Bangladesh & 0.254 & 154 & 0.390 & 0.261 & 0.254 & 0.095 \\
\hline Mauritania & 0.252 & 155 & 0.364 & 0.261 & 0.263 & 0.112 \\
\hline Sudan & 0.247 & 156 & 0.369 & 0.326 & 0.226 & 0.079 \\
\hline Madagascar & 0.246 & 157 & 0.408 & 0.325 & 0.220 & 0.048 \\
\hline Bhutan & 0.243 & 158 & 0.374 & 0.304 & 0.223 & 0.099 \\
\hline Angola & 0.240 & 159 & 0.344 & 0.305 & 0.218 & 0.134 \\
\hline Haiti & 0.240 & 160 & 0.396 & 0.327 & 0.211 & 0.067 \\
\hline Guinea-Bissau & 0.236 & 161 & 0.321 & 0.405 & 0.214 & 0.060 \\
\hline Senegal & 0.235 & 162 & 0.374 & 0.246 & 0.245 & 0.135 \\
\hline Chad & 0.234 & 163 & 0.352 & 0.359 & 0.202 & 0.087 \\
\hline Gambia & 0.232 & 164 & 0.346 & 0.290 & 0.293 & 0.071 \\
\hline Djibouti & 0.224 & 165 & 0.383 & 0.360 & 0.156 & 0.101 \\
\hline Mozambique & 0.211 & 166 & 0.383 & 0.331 & 0.207 & 0.079 \\
\hline Guinea & 0.206 & 167 & 0.386 & 0.305 & 0.212 & 0.097 \\
\hline Eritrea & 0.199 & 168 & 0.440 & 0.219 & 0.254 & 0.086 \\
\hline Burundi & 0.190 & 169 & 0.408 & 0.323 & 0.211 & 0.058 \\
\hline Ethiopia & 0.190 & 170 & 0.448 & 0.326 & 0.184 & 0.042 \\
\hline Sierra Leone & 0.179 & 171 & 0.339 & 0.307 & 0.293 & 0.061 \\
\hline Mali & 0.177 & 172 & 0.462 & 0.305 & 0.177 & 0.056 \\
\hline Burkina Faso & 0.161 & 173 & 0.501 & 0.208 & 0.206 & 0.085 \\
\hline Niger & 0.148 & 174 & 0.676 & 0.002 & 0.213 & 0.109 \\
\hline Sourc: Owa & & & & & \\
\hline
\end{tabular}

Source: Own computations based on UNDP (1998). 